\title{
Corn root and soil health indicator response to no-till production practices
}

\author{
Márcio R. Nunes ${ }^{\mathrm{a}, *}$, Douglas L. Karlen ${ }^{\mathrm{a}}$, José E. Denardin ${ }^{\mathrm{b}}$, Cynthia A. Cambardella ${ }^{\mathrm{a}}$ \\ ${ }^{a}$ United States Department of Agriculture (USDA), Agricultural Research Service (ARS), National Laboratory for Agriculture and the Environment (NLAE), 1015 N. \\ University Blvd., Ames, IA, 50011-3611, USA \\ ${ }^{\mathrm{b}}$ Embrapa Trigo, BR 285 Road, Passo Fundo, RS, 99001-970, Brazil
}

\section{A R T I C L E I N F O}

\section{Keywords:}

Soil compaction

Root growth

Soil structure

Soil organic carbon

Soil quality

\begin{abstract}
A B S T R A C T
Crop production guidelines in Brazil currently focus on soil fertility or chemical indicators (i.e., soil pH and nutrient availability) but often neglect physical and biological aspects of soil health. No-tillage (NT) practices have been widely adopted in Brazil primarily to mitigate erosion, but chemical-based guidelines associated with those practices may be contributing to nutrient stratification and a concentration of crop roots within the top few centimeters of the soil profile. Our objective was to quantify relationships between soil physical and chemical attributes and root growth in soils with a long-term NT history ( $>10$-yr). Crop root development and several soil health indicators were measured within the 0 to 7-, 7- to 17- and 20- to 30-cm depth increments of two long-term NT studies on Rhodic Hapludox soils in Brazil. Data from both experiments showed strong organic carbon (OC) stratification, significant differences in soil physical and chemical attributes, and root systems that were concentrated within the surface layer. Soil compaction below 7-cm appeared to be the dominant factor limiting root growth. Soil-test phosphorus (P) and OC were also correlated to root growth. Based on these analyses and other on-farm observations, we concluded that it is important to recognize that despite its benefits, NT practices can result in plant root stratification. Therefore, it is important to not only monitor soil fertility/chemical conditions, but also soil structure and biological indicators of soil health when developing NT guidelines for Brazil.
\end{abstract}

\section{Introduction}

No-till (NT) is being used worldwide on $>150 \mathrm{M}$ hectares of cropland. The greatest adoption is in South America where continuous NT is being used on nearly $100 \%$ of the cropland in Argentina and Paraguay and $70 \%$ of the arable land in Brazil (Kassam et al., 2015). NT has increased globally for both economic and environmental reasons. For example, when NT practices include permanent soil cover and cropping system diversification, it can significantly decrease runoff, soil erosion, and transport of sediments and nutrients to streams and lakes (Scopel et al., 2013; Baumhardt et al., 2015; Kassam et al., 2015). Adoption of NT practices can also increase soil organic carbon (OC), microbial biomass, and enzyme activity (Sharma et al., 2013; Kinoshita et al., 2017; Nunes et al., 2018). This stimulates formation and preservation of water stable aggregates (Bottinelli et al., 2017) and further improves soil water retention and movement (Dairon et al., 2017). However, NT may also result in stratification which leads to high nutrient and OC concentrations in surface layers (Baker et al., 2007; Luo et al., 2010; Houx et al., 2011; Deubel et al., 2011). It can also create subsurface layers that are compacted, thus reducing hydraulic conductivity, aeration, and water storage, while increasing hardness or penetration resistance (Suzuki et al., 2013; Dang et al., 2015).

Having favorable surface soil physical conditions but compacted subsurface layers can limit plant root growth within the soil profile. This significantly decreases the soil volume available for plant root exploration (Grzesiak et al., 2012), thus decreasing water and nutrient absorption and translocation (Fageria and Moreira, 2011) and ultimately results in plant water deficits and reduced crop yields. Important soil physical properties affecting plant root growth include macroporosity (MP), penetration resistance (PR) and available water capacity (Letey, 1985). Those soil characteristics directly affect oxygen and water availability, heat diffusion, and resistance to root penetration. Oxygen is essential for cell respiration and provides energy for plant metabolic processes. Low soil aeration can thus reduce root biomass as well as plant carotenoids, chlorophyll and protein content (Bennicelli et al., 1998; Ityel et al., 2014). Water is vital for photosynthesis, absorption, transport of nutrients and maintenance of cell wall turgor which are essential for promoting root growth. Soil PR also affects root elongation (Clark et al., 2003) and can decrease total root growth if it exceeds soil-specific limits (Imhoff et al., 2010; Lipiec et al., 2012).

The importance of a healthy soil chemical environment for plant

\footnotetext{
* Corresponding author.

E-mail addresses: marcio_r_nunes@usp.com.br, Marcio.Nunes@ars.usda.gov (M.R. Nunes).
} 
growth is well documented, as plants require soil nutrients to maintain normal biochemical and physiological cellular functions. For example, $\mathrm{P}$ is an integral part of phospholipids, phosphorylated sugars, proteins, deoxyribonucleic acid (DNA), ribonucleic acid (RNA) and adenosine 5triphosphate (ATP); while $\mathrm{K}$ is required for photosynthesis, protein synthesis, enzymes activity, and serves as a component in cell turgor (Blevins, 1994). Since most essential plant nutrients come from soil, any absence or reduced root growth can disrupt multiple processes that regulate ion movement into (or exclusion from) root tissues and thus reduce plant growth (Gabelman et al., 1986; Baligar et al., 1998).

Long-term NT generally results in the accumulation of nutrients, derived from fertilizers or extracted from deeper soil depths, at or near the soil surface. This increases soil fertility at the surface but results in much lower subsurface nutrient concentrations (Karathanasis and Wells, 1990; Selles et al., 1997). Subsurface nutrient deficiencies can affect root branching, length, and density (Eghball et al., 1993; Barber, 1995; Hoad et al., 2001; Fageria and Moreira, 2011). Previous studies have shown that deep placement of fertilizer can increase root length, proliferation and other morphological characteristics (Weligama et al., 2008). Those plant root changes cause nutrient uptake and crop yield to be different than when fertilizer is applied on the soil surface (Trapeznikov et al., 2003; Singh et al., 2005; Nash et al., 2013; Su et al., 2015).

Soil quality or health is assessed using soil biological, chemical and physical property and process indicators and can be used to guide land management decisions (Karlen et al., 1997). It expands on traditional soil fertility testing, which primarily focuses on chemical indicators (i.e., soil pH and nutrient concentrations; Karlen et al., 2003; MoebiusClune et al., 2016). Although traditional soil testing has proven very useful for increasing agricultural production, focusing only on soil chemical indicators can easily overlook physical and biological soil degradation (Andrews and Carroll, 2001; Magdoff and van Es, 2009; Nunes et al., 2017).

The use of soil quality assessment has increased in many countries such as Australia, China, India, and the United States. In Brazil, however, crop production guidelines are still being optimized based primarily on soil fertility models that focus almost exclusively on chemical indicators and neglect biological and physical aspects of soil fertility. Including soil biology and structure (i.e., physical measurements) in soil condition assessments for crop growth may be even more important for NT than tilled systems. Without tillage, soil structure, which reflects the combination or arrangement of primary soil particles into secondary units or peds that are characterized based on size, shape, and grade (i.e., degree of distinctness) is modified only by soil biota and plant roots. Therefore, developing crop production guidelines based on soil health assessments may help overcome problems being observed by producers using long-term NT practices. Our objective was to quantify relationships between soil physical and chemical indicators of soil health and corn (Zea mays L.) root growth within two Brazilian soils with longterm NT histories

\section{Materials and methods}

\subsection{Experimental location}

Soil health indicator data were collected from two field experiments conducted at the Brazilian Research Corporation (Embrapa) near Passo Fundo, RS, Brazil $\left(28^{\circ} 11^{\prime} \mathrm{S} ; 52^{\circ} 10^{\prime} \mathrm{W}\right)$. Based on the Köppen system, the regional climate is classified as humid subtropical (Cfa) with a uniformly distributed annual precipitation of 1300 to $1800 \mathrm{~mm}$. The field, which has gently rolling relief and had been used for NT crop production for more than 10 years, has a clay textured soil that is classified as Rhodic Hapludox \{Soil Taxonomy [USDA, 2012], Ferralic Nitisol [FAO, 2014] or Nitossolo Vermelho Distrófico latossólico [Brazilian Soil Classification System] (Santos et al., 2006)\}. The long-term cropping system included soybean [Glycine max (L.) Merr.] grown from October to March as the primary cash crop followed by wheat (Triticum aestivum L.) or fallow during winter (April to September).

\subsection{Experimental design}

\subsubsection{Site I}

This field study was conducted between September and February 2012, using a randomized block design with three treatments and four $48 \mathrm{~m}^{2}$ ( $6 \mathrm{~m}$ wide by $8 \mathrm{~m}$ long) replications (i.e., 12 plots). During this period, crops were sown using a seeder equipped with fixed shank openers that created furrows where seed and fertilizer were placed. See supplemental material for details about the no-till seeder used (Fig. S1). The treatments were defined by the depth of disturbance: FS5 $=5 \mathrm{~cm}$; FS7 $=7 \mathrm{~cm}$; and FS17 $=17 \mathrm{~cm}$. The FS5 and FS7 treatments represent the typical depth of disturbance within the region, while FS17 was selected to disrupt compacted subsurface layers. For this study corn was grown from September 2009 to February 2010, wheat from June 2010 to November 2010, soybean from November 2010 to March 2011, rye (Secale cereale L.) from April 2011 to September 2011, and corn from September 2011 to February 2012. For all crops, machinery traffic was restricted to the sowing operation. For additional details about the field study, please see Nunes et al. (2015a).

\subsubsection{Site II}

This field study was also conducted between September 2009 and February 2012, using a randomized block design with six treatments and four $48 \mathrm{~m}^{2}$ ( $6 \mathrm{~m}$ wide by $8 \mathrm{~m}$ long) replications (i.e., 24 plots). The treatments were defined based on the amount of time NT that had elapsed since a chiseling operation: i.e., C24 $=24$ months after chiseling in Sept. 2009; C18 = 18 months after chiseling in Mar. 2010; C12 = 12 months after chiseling in Sept. 2010; C6 = 6 months after chiseling in Mar 2011; C0 = sowing immediately after chiseling; and NT12 = 12 years of continuous NT. At this site, chisels reached a depth of approximately $25-\mathrm{cm}$ using an implement equipped with five fixed shanks placed at $30-\mathrm{cm}$ intervals and followed by a roller-harrow. The crop sequence for each phase of the experiment was the same as at Site I. Machinery traffic at this site was restricted to sowing and chiseling operations. For additional details about the Site II experiment, please see Nunes et al. (2015b).

\subsection{Soil and root sampling and analyses}

\subsubsection{Plant root growth}

In December 2011, corn root proliferation was evaluated in $60 \mathrm{~cm}$ wide, $30 \mathrm{~cm}$ high and $5 \mathrm{~cm}$ thick $\left(9 \mathrm{dm}^{3}\right)$ soil and root monoliths collected from each plot using a nail-plate technique (Bohm, 1979). The crop was at the R3 phenological growth stage (i.e., milk stage, 18 to 22 days after silking). After dispersing and removing soil from each monolith, the root system was divided into three layers: 0- to 7-, 7- to 17- and 17- to $30-\mathrm{cm}$. The roots contained in each layer were placed in a container with a small amount of water, organized in a way that they did not overlap and quantified by digitizing with a HP Scanjet 3570C scanner (Hewlett Packard, Brazil). Root length and volume were computed using Safira software (Jorge and Rodrigues, 2008). The roots were subsequently oven dried at $65^{\circ} \mathrm{C}$ in order to determine dry matter mass. Root density (RD; $\mathrm{kg} \mathrm{m}^{-3}$ ) was estimated using the ratio between root dry matter mass and soil volume for each layer. Root length (RL; $\mathrm{cm} \mathrm{cm}^{-3}$ ) was calculated using a root length to soil volume ratio for each layer, where root volume $\left(\mathrm{RV} ; \mathrm{cm}^{3} \mathrm{~cm}^{-3}\right)$ was estimated by dividing root volume by soil volume for each layer.

\subsubsection{Soil physical and chemical attributes}

Following corn harvest in February 2012, 30-cm deep soil pits were opened perpendicular to the chisel direction in control treatments for experiment I (FS5) and experiment II (NT12) to visually evaluate and characterize soil structure. The soil showed three distinct layers: i) 0 - to 
7-cm, characterized by soil aggregates of various size and having visible pores; ii) 7 - to $20-\mathrm{cm}$, characterized by massive soil structure, without visible pores; iii) $>20-\mathrm{cm}$, dense but generally less compacted. Based on this field evaluation, six undisturbed soil samples were collected from the 2- to 5-cm (layer i), 9- to 12-cm (layer ii), and 25- to $28-\mathrm{cm}$ (layer iii) within each plot using stainless cylinders (48-mm Internal Diameter; 30-mm Hight). Similar soil pits within all other treatments were subsequently opened and sampled following the same procedures.

Three of the undisturbed samples were used to assess soil macroporosity (MP) using a tension table method (Donagema et al., 2011) and soil bulk density (BD) according to Grossman and Reinsch (2002). MP was quantified at $6 \mathrm{kPa}$. Soil penetration resistance (PR) was measured on the other three samples a water potential equilibrated at $-10 \mathrm{kPa}$ using a bench-mounted electronic penetrometer equipped with a $3-\mathrm{mm}$ diameter cone, $30^{\circ}$ semi-angle, variable speed, and data acquisition system (Marconi Model MA 933).

Disturbed samples were also collected from each depth increment within every soil pit and dried under shaded conditions until they were friable. Samples were then pushed through a 9.52-mm mesh sieve, breaking aggregates larger than $9.52 \mathrm{~mm}$ along their weak planes. A portion of this sample was used to quantify wet aggregate stability as outlined by Kemper and Rosenau (1986). Briefly, a 50-g dry weight sample was put on filter paper placed on the top sieve of a nest consisting of sieves with 4.76, 2.0, 1.0, 0.25- and 0.105-mm openings. The sieve set was placed in water which reached the bottom of the $4.76 \mathrm{~mm}$ sieve, thus enabling the soil samples to wet through capillarity. The sieve set was then oscillated for $10 \mathrm{~min}$ at a rate of $3.5-\mathrm{cm}$ per minute. Aggregates distributed on each the sieves after this period were oven dried at $105^{\circ} \mathrm{C}$ for $24 \mathrm{~h}$ and weighed. They were then submerged in $1 \mathrm{~mol} \mathrm{~L}^{-1} 6 \%$ sodium hydroxide solution for one night. The soil material from each sieve was washed away and the inert material (e.g, gravel, sand and crop residues) was determined after oven drying.

The mean weight diameter (MWD) of the aggregates was estimated using the equation:

$M W D=\left[\frac{\sum_{i=1}^{n} D M i(M A G R i-m i)}{\sum_{i=1}^{n}(M A G R i-m i)}\right]$

where MAGRi is the aggregate mass plus size-class $i$ inert material, mi is the inert material mass (gravel, sand, roots, crop residues) in class $i$; and DMi the mean diameter in class $\mathrm{i}(\mathrm{mm})$. The aggregates were also separated into those larger than 2-mm (A $>2 \mathrm{~mm}$ ).

Part of the disturbed soil sample was analyzed for chemical attributes using techniques described by Donagema et al. (2011). This included: $\mathrm{pH}$ in water using a 1:1 (soil:water) ratio; extraction of exchangeable calcium (Ca) and aluminum (Al) with $1 \mathrm{~mol} \mathrm{~L}^{-1} \mathrm{KCl}$ after which $\mathrm{Ca}$ was determined with an atomic absorption spectrophotometer and $\mathrm{Al}$ by titration with $\mathrm{NaOH}$; available potassium (K) content measured by the Mehlich-1 method and analyzed by flame photometry; and phosphorus content (P) extracted using Melich-1 solution. Organic carbon (OC) was assessed using the Walkley-Black method presented by Tedesco et al. (1995). Soil C stocks were calculated using the methodology described in Ellert and Bettany (1995) to correct soil $\mathrm{C}$ stocks to an equivalent soil mass. The soil mass in the treatments FS17 and C0 was considered as the reference soil mass in Site I and Site II, respectively.

\footnotetext{
${ }^{1}$ Mention of any product or brand name or trademark does not constitute an endorsement of the product or company by the United States Department of Agriculture. Parts are specified by name or part number for reference purposes only and are used to facilitate communication and illustration of the system described herein. Any part or material from any company that provides equivalent function may be used.
}

\subsection{Data analysis}

Treatment effects on soil properties and root growth were assessed separately for each experiment using an analysis of variance (ANOVA). Differences between treatment means for each soil layer were evaluated using the Tukey test $(\alpha=0.05)$. Anticipated relationships between plant root growth, soil physical, and chemical indicators were evaluated after combining results from both experiments. This included: (1) exploratory analysis considering root indicators and measured soil attributes with bivariate scatterplots and Pearson correlation coefficients; (2) determining relationship strength between root growth (Group I) and soil (Group II) indicators with multivariable canonical correlations supported by F-tests $(\alpha=0.05)$ as recommended by Manly (2005):

$\left[\begin{array}{l}\text { Group I:Root group } \\ \mathrm{RD}+\mathrm{RL}+\mathrm{RV}\end{array}\right] \mathrm{vs}[\mathrm{BD}+\mathrm{PR}+\mathrm{MP}+\mathrm{A}>2 \mathrm{~mm}+\mathrm{MWD}+\mathrm{SOC}+\mathrm{pH}+\mathrm{Al}+\mathrm{K}+\mathrm{P}+\mathrm{Ca}]$

and 3) linear regression using the most important variables within each group and with multiple variables to parametrize the root growth variables as linear combinations of soil chemical and physical indicators. Analyses were performed independently for each soil layer and by using combined data from all three soil layers. The analyses were conducted within the $\mathrm{R}$ statistical computing environment ( $\mathrm{R}$ Core Team, 2016).

\section{Results}

\subsection{Soil properties and root growth arrangement on the soil profile}

\subsubsection{Experiment I}

The 30-cm deep soil profile evaluations within the FS5 and FS7 treatments showed physical stratification that was affecting corn root development and distribution (Table 1). Within the surface seven centimeters, MP was $0.20 \mathrm{~m}^{3} \mathrm{~m}^{-3}$ while the $\mathrm{PR}$ and $\mathrm{BD}$ values were $\sim 1.1 \mathrm{MPa}$ and $\sim 1.1 \mathrm{~g} \mathrm{~cm}^{-3}$, respectively. From 7 - to $17-\mathrm{cm}$ MP was lower $\left(\sim 0.08 \mathrm{~m}^{3} \mathrm{~m}^{-3}\right)$ but PR ( $\left.\sim 3.1 \mathrm{MPa}\right)$ and BD $\left(1.41 \mathrm{~g} \mathrm{~cm}^{-3}\right)$ were higher. Soil physical conditions from $20-$ to $30-\mathrm{cm}$ were worse than in the topsoil, but better than within the 7- to $17-\mathrm{cm}$ layer. Use of a seeder equipped with fixed shank openers, tilling to a depth of approximately 17-cm (FS17) reduced the soil physical stratification under NT as shown by increased MP and decreased PR and BD within the 7- to 17-cm soil layer (Table 1). The depth of fixed shank tillage did not change the fraction of soil aggregates $>2 \mathrm{~mm}$ or the MWD (Table 1 ).

Soil chemical indicators also showed stratification within the surface $30-\mathrm{cm}$ of the long-term NT treatments (Table 2). The topsoil (0- to 7-cm) had the highest mean OC $\left(19.2 \mathrm{~g} \mathrm{~kg}^{-1}\right), \mathrm{K}\left(179.8 \mathrm{mg} \mathrm{m}^{-3}\right)$ and $\mathrm{P}$ $\left(36.29 \mathrm{mg} \mathrm{dm}^{-3}\right)$ concentrations; while the 20 - to $30-\mathrm{cm}$ layer had the lowest OC $\left(11.4 \mathrm{~g} \mathrm{~kg}^{-1}\right), \mathrm{K}\left(63.33 \mathrm{mg} \mathrm{m}^{-3}\right)$ and $\mathrm{P}\left(2.76 \mathrm{mg} \mathrm{m}^{-3}\right)$ concentrations; and the 7- to 17-cm layer had intermediate concentration $\left[13.1 \mathrm{~g} \mathrm{~kg}^{-1}, 141.5 \mathrm{mg} \mathrm{m}^{-3}\right.$, and $11.9 \mathrm{mg} \mathrm{dm}^{-3}$ for $\mathrm{OC}, \mathrm{K}$, and $\mathrm{P}$, respectively (Table 2)]. The use of fixed shank openers tilling to a depth of $17 \mathrm{~cm}$ (FS17) had no effect on most of the soil chemical indicators, although OC (concentration and stocks) in the 7- to $17-\mathrm{cm}$ soil layer was increased (Table 2).

The corn root system was also concentrated in the topsoil layer under NT (Fig. 1). Mean RD, RL and RV values within the 0- to 7-cm layer were $4.03 \mathrm{~kg} \mathrm{~m}^{-3}, 4.93 \mathrm{~cm} \mathrm{~cm}^{-3}$, and $0.19 \mathrm{~cm}^{3} \mathrm{~cm}^{-3}$, respectively. From 7- to $17-\mathrm{cm}$, mean values were lower: $0.72 \mathrm{~kg} \mathrm{~m}^{-3}$ (RD), $1.94 \mathrm{~cm} \mathrm{~cm}^{-3}$ (RL), and $0.05 \mathrm{~cm}^{3} \mathrm{~cm}^{-3}$ (RV); and within the 20- to 30 $\mathrm{cm}$ layer, they were even lower $\left(0.19 \mathrm{~kg} \mathrm{~m}^{-3}, 1.42 \mathrm{~cm} \mathrm{~cm}^{-3}\right.$, and $0.02 \mathrm{~cm}^{3} \mathrm{~cm}^{-3}$ for $\mathrm{RD}, \mathrm{RL}$, and $\mathrm{RV}$, respectively) (Fig. 1). Corn root growth was influenced by the depth at which the openers operated, as indicated by significantly higher RD, RL, and RV values at the 7- to 17cm depth in FS17 compared to FS5 (Fig. 1).

\subsubsection{Experiment II}

Physical and chemical stratification within the NT soil profile was 
Table 1

Means (standard errors) for physical properties of a soil under no-till submitted to corn sowing with a seeder equipped with fixed shank openers working at different depth.

\begin{tabular}{|c|c|c|c|c|c|c|}
\hline Layer & Treatment $^{\dagger}$ & $\mathrm{BD}, \mathrm{g} \mathrm{cm}^{-3}$ & $\mathrm{PR}, \mathrm{MPa}$ & MP, $\mathrm{m}^{3} \mathrm{~m}^{-3}$ & $\mathrm{~A}>2 \mathrm{~mm}, \%$ & MWD, mm \\
\hline \multirow[t]{3}{*}{$0-7 \mathrm{~cm}$} & FS5 & $1.10^{( \pm 0.12)} \mathrm{a}$ & $1.13^{( \pm 0.15)} \mathrm{a}$ & $0.19^{( \pm 0.05)} \mathrm{a}$ & $48.54^{( \pm 3.40)} \mathrm{a}$ & $3.25^{( \pm 0.13)} \mathrm{a}$ \\
\hline & FS7 & $1.11^{( \pm 0.06)} \mathrm{a}$ & $1.11^{( \pm 0.04)} \mathrm{a}$ & $0.21^{( \pm 0.03)} \mathrm{a}$ & $49.13^{( \pm 6.48)} \mathrm{a}$ & $3.25^{( \pm 0.56)} \mathrm{a}$ \\
\hline & FS17 & $1.15^{( \pm 0.07)} \mathrm{a}$ & $1.06^{( \pm 0.14)} \mathrm{a}$ & $0.17^{( \pm 0.05)} \mathrm{a}$ & $49.95^{( \pm 1.63)} \mathrm{a}$ & $3.27^{( \pm 0.01)} \mathrm{a}$ \\
\hline \multirow[t]{3}{*}{$7-17 \mathrm{~cm}$} & FS5 & $1.41^{( \pm 0.03)} \mathrm{a}$ & $3.17^{( \pm 0.58)} \mathrm{a}$ & $0.07^{( \pm 0.01)} \mathrm{b}$ & $48.26^{( \pm 6.90)} \mathrm{a}$ & $3.50^{( \pm 0.32)} \mathrm{a}$ \\
\hline & FS7 & $1.41^{( \pm 0.05)} \mathrm{a}$ & $3.12^{( \pm 0.69)} \mathrm{a}$ & $0.08^{( \pm 0.01)} \mathrm{b}$ & $51.50^{( \pm 2.49)} \mathrm{a}$ & $2.96^{( \pm 0.31)} \mathrm{a}$ \\
\hline & FS17 & $1.20^{( \pm 0.03)} \mathrm{b}$ & $1.31^{( \pm 0.37)} \mathrm{b}$ & $0.15^{( \pm 0.01)} \mathrm{a}$ & $49.20^{( \pm 1.31)} \mathrm{a}$ & $3.38^{( \pm 0.01)} a$ \\
\hline \multirow[t]{3}{*}{$20-30 \mathrm{~cm}$} & FS5 & $1.36^{( \pm 0.07)} \mathrm{a}$ & $2.74^{( \pm 0.65)} \mathrm{a}$ & $0.06^{( \pm 0.01)} \mathrm{a}$ & $35.42^{( \pm 1.38)} \mathrm{a}$ & $2.04^{( \pm 0.08)} \mathrm{a}$ \\
\hline & FS7 & $1.36^{( \pm 0.03)} \mathrm{a}$ & $2.36^{( \pm 0.07)} \mathrm{a}$ & $0.06^{( \pm 0.01)} \mathrm{a}$ & $38.30^{( \pm 6.04)} \mathrm{a}$ & $2.41^{( \pm 0.70)} \mathrm{a}$ \\
\hline & FS17 & $1.30^{( \pm 0.05)} \mathrm{a}$ & $2.44^{( \pm 0.46)} \mathrm{a}$ & $0.07^{( \pm 0.01)} \mathrm{a}$ & $37.15^{( \pm 4.99)} \mathrm{a}$ & $2.28^{( \pm 0.40)} \mathrm{a}$ \\
\hline
\end{tabular}

† FS5, fixed shank openers working at 5-cm depth; FS7, fixed shank openers working at 7-cm depth; FS17, fixed shank openers working at 17-cm depth. BD: bulk density, PR: penetration resistance, MP: macroporosity, A $>2 \mathrm{~mm}$ : aggregates larger than $2 \mathrm{~mm}$, MWD: mean weight diameter of the aggregates. Means of each property followed by the same lowercase letter within a column (inside of each soil layer) are not significantly different at $\alpha=0.05$ based on Tukey`s test. Note: Cited and adapted from Nunes et al. (2015a), as critical background information.

Table 2

Means (standard errors) for chemical properties of a soil under no-till submitted to corn sowing with a seeder equipped with fixed shank openers working at different depth.

\begin{tabular}{|c|c|c|c|c|c|c|c|c|}
\hline Layer & Treatment $^{\dagger}$ & $\begin{array}{l}\text { SOC } \\
\%\end{array}$ & $\begin{array}{l}\mathrm{SOC}_{\mathrm{ESM}} \\
\mathrm{Mg} \mathrm{ha}^{-1}\end{array}$ & $\mathrm{pH}$ & $\mathrm{Al}$ & $\mathrm{Ca}$ & $\mathrm{K}$ & $\mathrm{P}$ \\
\hline \multirow[t]{4}{*}{$0-7 \mathrm{~cm}$} & FS5 & $1.84^{( \pm 0.06)} \mathrm{a}$ & $14.81^{( \pm 0.46)} \mathrm{a}$ & $5.00^{( \pm 0.34)} \mathrm{a}$ & $13.83^{( \pm 0.78)} \mathrm{a}$ & $31.6^{( \pm 2.1)} \mathrm{a}$ & $170.7^{( \pm 27.2)} \mathrm{a}$ & $39.3^{( \pm 13.8)}$ \\
\hline & FS7 & $\left.1.98^{( \pm 0.05}\right) \mathrm{a}$ & $15.97^{( \pm 1.76)} \mathrm{a}$ & $4.98^{( \pm 0.28)} \mathrm{a}$ & $12.37^{( \pm 5.64)} \mathrm{a}$ & $34.1^{( \pm 7.3)} \mathrm{a}$ & $182.7^{( \pm 70.2)} \mathrm{a}$ & $34.8^{( \pm 12.6)}$ \\
\hline & FS17 & $1.93^{( \pm 0.22)} \mathrm{a}$ & $14.81^{( \pm 0.40)} \mathrm{a}$ & $5,13^{( \pm 0.30)} \mathrm{a}$ & $10.97^{( \pm 4.96)} \mathrm{a}$ & $36.1^{( \pm 5.3)} \mathrm{a}$ & $186.0^{( \pm 43.9)} \mathrm{a}$ & $34.8^{( \pm 18.4)}$ \\
\hline & Mean & $1.92^{( \pm 0.14)}$ & $15.20^{( \pm 0.87)}$ & $5.03^{( \pm 2.28)}$ & $12.39^{( \pm 4.13)}$ & $34.0^{( \pm 5.2)}$ & $179.8^{( \pm 46.0)}$ & $36.3^{( \pm 5.2)}$ \\
\hline \multirow[t]{4}{*}{$7-17 \mathrm{~cm}$} & FS5 & $1.33^{( \pm 0.03)} \mathrm{ab}$ & $15.92^{( \pm 0.41)} \mathrm{ab}$ & $5.40^{( \pm 0.08)} \mathrm{a}$ & $6.70^{( \pm 1.76)} \mathrm{a}$ & $39.9^{( \pm 4.1)} \mathrm{a}$ & $152.0^{( \pm 49.2)} \mathrm{a}$ & $10.3^{( \pm 5.4)} \mathrm{a}$ \\
\hline & FS7 & $1.24^{( \pm 0.05)} \mathrm{b}$ & $14.92^{( \pm 0.61)} \mathrm{b}$ & $5.35^{( \pm 0.13)} \mathrm{a}$ & $8.08^{( \pm 1.70)} \mathrm{a}$ & $41.8^{( \pm 3.5)} \mathrm{a}$ & $139.0^{( \pm 55.8)} \mathrm{a}$ & $11.0^{( \pm 3.9)} \mathrm{a}$ \\
\hline & FS17 & $1.36^{( \pm 0.08)} \mathrm{a}$ & $16.36^{( \pm 0.96)} \mathrm{a}$ & $5.40^{( \pm 0.18)} \mathrm{a}$ & $6.85^{( \pm 2.37)} \mathrm{a}$ & $44.2^{( \pm 5.6)} \mathrm{a}$ & $133.5^{( \pm 29.0)} \mathrm{a}$ & $14.3^{( \pm 7.2)} \mathrm{a}$ \\
\hline & Mean & $1.31^{( \pm 0.07)}$ & $15.73^{( \pm 0.66)}$ & $5.38^{( \pm 0.13)}$ & $7.21^{( \pm 1.89)}$ & $41.9^{( \pm 4.4)}$ & $141.5^{( \pm 42.4)}$ & $11.9^{( \pm 5.4)}$ \\
\hline \multirow[t]{4}{*}{$20-30 \mathrm{~cm}$} & FS5 & $1.15^{( \pm 0.15)} \mathrm{a}$ & $15.27^{( \pm 1.57)} \mathrm{a}$ & $5.33^{( \pm 0.15)} \mathrm{a}$ & $12.40^{( \pm 3.69)} \mathrm{a}$ & $31.5^{( \pm 7.2)} \mathrm{a}$ & $71.5^{( \pm 29.2)} \mathrm{a}$ & $2.5^{( \pm 1.1)} \mathrm{a}$ \\
\hline & FS7 & $1.17^{( \pm 0.014)} \mathrm{a}$ & $15.59^{( \pm 1.88)} \mathrm{a}$ & $5.45^{( \pm 0.13)} \mathrm{a}$ & $7.93^{( \pm 2.07)} \mathrm{a}$ & $32.6^{( \pm 2.5)} \mathrm{a}$ & $62.5^{( \pm 32.3)} \mathrm{a}$ & $2.8^{( \pm 1.6)} \mathrm{a}$ \\
\hline & FS17 & $1.10^{( \pm 0.30)} \mathrm{a}$ & $14.57^{( \pm 3.97)} \mathrm{a}$ & $5.55^{( \pm 0.15)} \mathrm{a}$ & $11.15^{( \pm 2.05)} \mathrm{a}$ & $32.5^{( \pm 8.7)} \mathrm{a}$ & $56.0^{( \pm 13.5)} \mathrm{a}$ & $3.1^{( \pm 1.8)} \mathrm{a}$ \\
\hline & Mean & $1.14^{( \pm 0.19)}$ & $15.14^{( \pm 1.81)}$ & $5.41^{( \pm 0.14)}$ & $10.49^{( \pm 3.15)}$ & $32.2^{( \pm 6.0)}$ & $63.3^{( \pm 24.7)}$ & $2.8^{( \pm 1.4)}$ \\
\hline
\end{tabular}

${ }^{\dagger}$ FS5, fixed shank openers working at 5-cm depth; FS7, fixed shank openers working at 7-cm depth; FS17, fixed shank openers working at 17-cm depth. SOC: soil organic carbon; $\mathrm{SOC}_{\mathrm{ESM}}$ : soil organic carbon on an equivalent soil mass (soil mass in the FS17 treatment was used as reference, as follow: layer 0-7 cm $=805 \mathrm{Mg}$ $\mathrm{ha}^{-1}$; layer 7-17 $\mathrm{cm}=1200 \mathrm{Mg} \mathrm{ha}^{-1}$; layer $20-30 \mathrm{~cm}=1300 \mathrm{Mg} \mathrm{ha}^{-1}$ ). Means of each property followed by the same lowercase letter within a column (inside of each soil layer) are not significantly different at $\alpha=0.05$ based on Tukey`s test. Capital letters show significance of overall treatments for layer.

also observed in Experiment II [i.e., treatment NT12 (Tables 3 and 4)]. Soil MP as well as K, P, and OC concentrations were higher in the 0 - to 7-cm layer than in either the 7- to 17- or 20- to 30-cm layers. Meanwhile, PR and BD were lower in the 7- to $17-\mathrm{cm}$ and 20 - to $30-\mathrm{cm}$ layers (Tables 3 and 4). Furthermore, as noted for Experiment I, the root system was found to be concentrated in the topsoil layer (Fig. 2).

Chiseling did not change nutrient concentrations or OC in the 0 - to $30-\mathrm{cm}$ layer or the soil physical attributes within the 0 - to 7- and 20- to 30-cm layers (Tables 3 and 4). In contrast, chiseling did mitigate soil compaction within the 7- to 17-cm depth. This significantly decreased PR and BD and increased MP (Table 3) as well as root growth (RD and RL) in that subsurface soil layer (Fig. 2). The chiseling effects on soil physical properties and root growth were relatively short-lived, continuing for only three crops after the operation [C0, C6, and $\mathrm{C} 12$ (Table 3 and Fig. 2)]. After 18 months the positive effects of chiseling were no longer evident, confirming the short-term effect it has in Brazilian NT soils.

\subsection{Relationship between root growth and soil attributes}

The bivariate scatterplots presented for each of the root indicator (RD, RL, and RV) and soil attribute clearly distinguish the soil layers (Fig. 3). Regardless of the treatment, root concentration was higher in the topsoil than in subsurface layers. The exploratory analysis also suggested differences in how the various corn root indicators related to soil attributes in the various layers (Fig. 3). For example, within the 0 to
7- and 20- to 30-cm layers, the two-dimensional data visualization (scatterplots), suggested no strong relationship between root indicators and soil attributes (Fig. 3), which was further confirmed by the Pearson correlation coefficients (Table 5). In contrast, within the 7- to $17-\mathrm{cm}$ layer, the scatterplot suggested clear and strong relationships between root growth and soil attributes, especially for the soil physical indicators, which was also further confirmed by the Pearson correlation within this soil layer (Table 5). For example, within this layer (7- to 17$\mathrm{cm})$, the RD was strongly correlated with BD (-0.997), PR (-0.995) and MP (0.989); RL was strongly correlated with BD (-0.921), PR (-0.931) and MP (0.898) (Table 5). In addition, the scatterplots and Person coefficients from the 0 - to $30-\mathrm{cm}$ (i.e., combined dataset from all three layers) also showed significant relationships between root growth and the measured soil attributes.

Results of separate canonical correlation analyses for the topsoil and 20- to 30-cm layers showed no significant correlation between group I and Group II, confirming the weak relationship between root growth indicators and soil attributes for those layers (Table 6). In contrast, results for the 7- to $17-\mathrm{cm}$ layer and $0-$ to $30-\mathrm{cm}$ combined dataset for all three layers, showed a strong correlation between Group I (root growth) and Group II (soil attributes). For the 7- to 17-cm layer, the first canonical pair was significantly associated with a canonical correlation of 0.967 between Group I and Group II, explaining $94.8 \%$ of the total covariance. For the entire 0 to $30-\mathrm{cm}$ depth, the canonical correlation was 0.957 , explaining $98.6 \%$ of the total covariance between the groups (Table 6). The second and third canonical pairs in both layers were not 

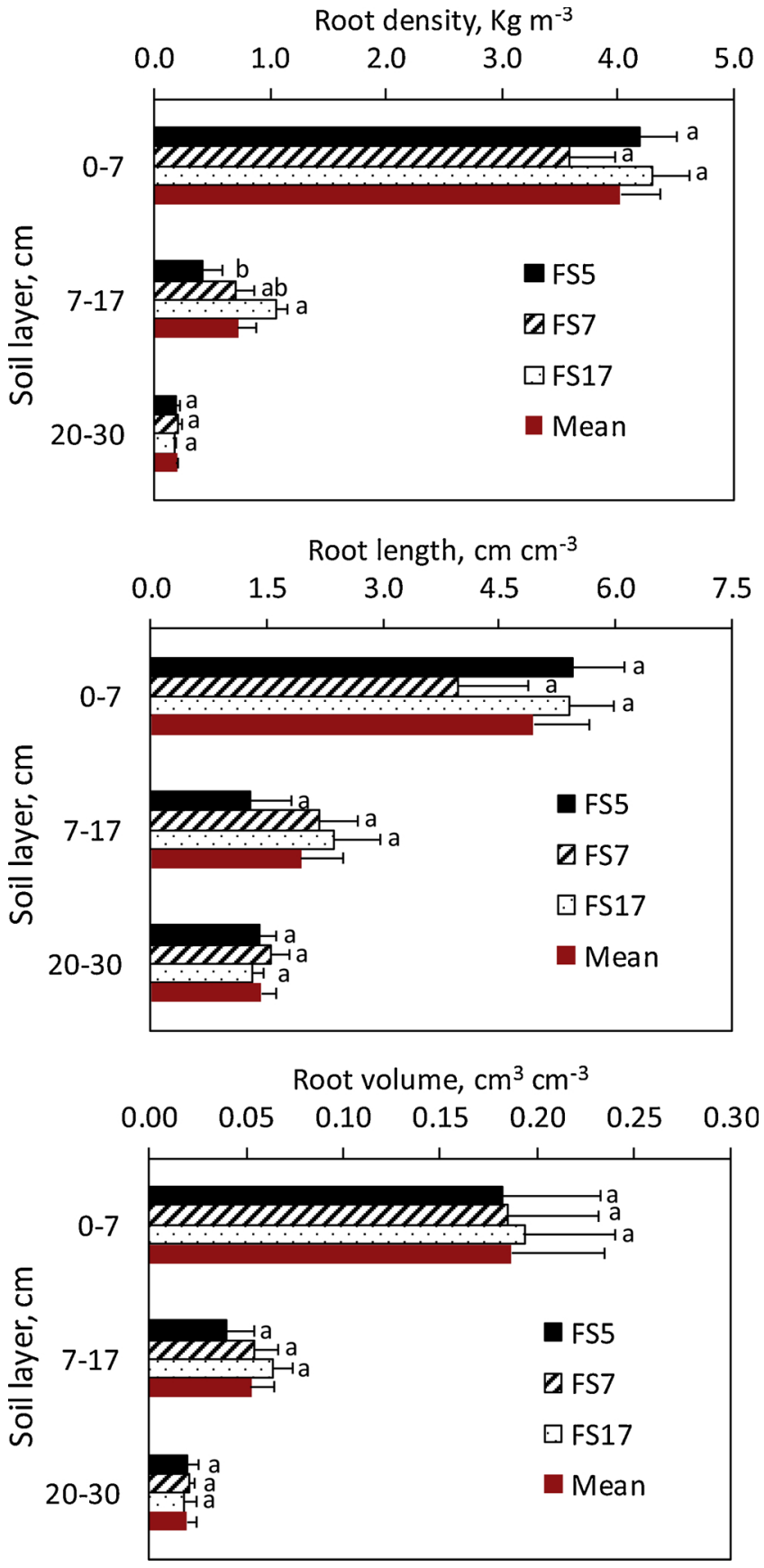

Fig. 1. Root density, root length density and root volume density of corn plants sowed with a seeder equipped with fixed shank openers working at 5-cm (FS5), 7-cm (FS7) and 17-cm (FS17) depth in a soil under no-till for over 12-year. Horizontal bars indicate standard deviation. The same lowercase letter (within each soil layer) are not significantly different at $\alpha=0.05$ based on Tukey`s test. Capital letters show significance of overall treatments for layer.

\section{significant.}

Canonical coefficients for variables within the first pair were also estimated using a maximum covariance model (canonical weights) as presented in Table 6. Values of the canonical coefficients for the Group II variables permit identification of the soil attributes that are most important within the linear combinations of Group I with regard to canonical root growth variables of Group II. For the 7- to 17-cm layer, the most important Group II variables were PR and BD. For the 0 to 30 $\mathrm{cm}$ depth, OC, MP, PR, BD, and P emerged as the most important Group II variables for prediction of Group I canonical variables. However, the weight for OC was much greater than other Group II variables. This indicates that for the compacted subsurface layer of NT soils, root growth was influenced most by soil physical conditions (PR and BD) while for the 0 to $30-\mathrm{cm}$ layer, root growth was influenced most by OC content, physical conditions (MP, PR, BD) and P concentrations.

Having identified the most important soil attributes for predicting root growth in the subsurface layer $(7-$ to $17-\mathrm{cm})$ and 0 to $30-\mathrm{cm}$ soil layer (combined dataset from the three layers), our next objective was to establish functional relationships between the three corn root indicator variables and the soil attributes, through stepwise multiple regression that treated RD, RL, and RV as dependent variables. For the 7to 17-cm layer, PR and BD were the most important variables in the canonical analyses, while MP, OC and $\mathrm{pH}$ showed high Pearson correlation coefficients. For the combined 0 to $30-\mathrm{cm}$ layer, the initial set of explanatory variables was $\mathrm{OC}, \mathrm{MP}, \mathrm{RP}, \mathrm{BD}$, and $\mathrm{P}$ using canonical analyses, and $\mathrm{K}, \mathrm{A}>2 \mathrm{~mm}$, MWD and $\mathrm{pH}$ with Pearson correlation. Linear equations with optimized parameter values obtained from the model adjustment are presented in Table 7. For the 7- to 17-cm layer, all root growth equations included only soil physical indicators (PR, BD, and MP). For the 0 to $30-\mathrm{cm}$ layer, OC and MP were included as a term in the equations, thus demonstrating the influence of $\mathrm{OC}$ with regard to soil aeration for root growth. In addition to OC and MP, the root growth in the first 30-cm soil profile under NT was dependent of PR and P concentrations.

\section{Discussion}

Field effects of the various treatments were previously discussed by Nunes et al. (2015a; and 2015b) and will not be repeated herein. Rather, this discussion will focus on soil properties and root system responses within the long-term NT soil profile.

It is well documented that NT is one of the most important strategies for conservation agriculture. Continuous NT managed using diversified cropping systems and permanent soil cover provided by mulching and/ or cover crops has improved soil health in many studies (e.g., Kinoshita et al., 2017; Nunes et al., 2018). Our results, however, show that the soil profile under long-term NT managed without other soil enhancing practices developed strong stratification of biological, physical and chemical attributes. Nutrients ( $\mathrm{K}$ and $\mathrm{P}$ ) and $\mathrm{OC}$ tended to accumulate in the topsoil while the subsurface layer tended to have a high degree of compaction, resulting in poor aeration and high PR. Stratification of soil profiles under NT was also reported by other authors (e.g., Luo et al., 2010; Houx et al., 2011; Deubel et al., 2011; Suzuki et al., 2013; Dang et al., 2015).

Repeated machine traffic tends to promote soil compaction to a depth of $\sim 20$-cm under long-term NT (Reichert et al., 2009; Suzuki et al., 2013; Nunes et al., 2015a). However, compaction was not observed in the topsoil layer due to wetting and drying cycles as well as the concentration of OC and plant roots (Table 2 and 4; Fig. 1 and 2) which are both known to improve soil aggregation (Horn and Peth, 2009; Silva et al., 2014b). Furthermore, soil disturbance by the coulters and shanks attached to NT seeders also help mitigate near-surface soil compaction (Silva et al., 2014a; Nunes et al., 2015a). Nutrients from fertilizer and crop residue also tend to accumulate near the soil surface under NT and thus contribute to chemical stratification. Over time, this combination of factors results in a surface layer with high $\mathrm{P}, \mathrm{K}$ and $\mathrm{OC}$ content (Karathanasis and Wells, 1990; Selles et al., 1997) and subsurface layers with low nutrient availability and high soil compaction. This restricts plant root growth to the topsoil (Figs. 1 and 2), decreasing the soil volume explored by the roots and absorption and translocation of water and nutrients from the soil to plant tops (Fageria and Moreira, 2011; Grzesiak et al., 2012). In addition to affecting nutrient uptake, concentrating plant roots in the topsoil can also decrease crop yield, especially in response to short periods of drought (Hamza and Anderson, 2005).

It is frequently claimed that long-term NT increases $\mathrm{C}$ content in the 
Table 3

Means (standard errors) for soil physical properties as a function of time after chisel tillage under no-till.

\begin{tabular}{|c|c|c|c|c|c|c|}
\hline Layer & Treatment $^{\dagger}$ & $\mathrm{BD}, \mathrm{g} \mathrm{cm}^{-3}$ & $\mathrm{PR}, \mathrm{MPa}$ & $\mathrm{MP}, \mathrm{m}^{3} \mathrm{~m}^{-3}$ & $\mathrm{~A}>2 \mathrm{~mm}, \%$ & MWD, mm \\
\hline \multirow[t]{6}{*}{$0-7 \mathrm{~cm}$} & $\mathrm{CO}$ & $1.11^{( \pm 0.02)} \mathrm{a}$ & $1.06^{( \pm 0.01)} \mathrm{a}$ & $0.20^{( \pm 0.03)} \mathrm{a}$ & $44.81^{( \pm 4.93)} \mathrm{a}$ & $3.06^{( \pm 0.43)} \mathrm{a}$ \\
\hline & C6 & $\left.1.10^{( \pm 0.08}\right) \mathrm{a}$ & $0.97^{( \pm 0.05)} \mathrm{a}$ & $0.19^{( \pm 0.05)} \mathrm{a}$ & $48.24^{( \pm 3.26)} \mathrm{a}$ & $3.20^{( \pm 0.26)} \mathrm{a}$ \\
\hline & $\mathrm{C} 12$ & $1.05^{( \pm 0.12)} \mathrm{a}$ & $0.92^{( \pm 0.05)} \mathrm{a}$ & $0.23^{( \pm 0.03)} \mathrm{a}$ & $47.23^{( \pm 6.59)} \mathrm{a}$ & $3.02^{( \pm 0.58)} \mathrm{a}$ \\
\hline & $\mathrm{C} 18$ & $1.19^{( \pm 0.12)} \mathrm{a}$ & $1.04^{( \pm 0.05)} \mathrm{a}$ & $0.18^{( \pm 0.04)} \mathrm{a}$ & $47.18^{( \pm 3.82)} \mathrm{a}$ & $3.08^{( \pm 0.66)} a$ \\
\hline & $\mathrm{C} 24$ & $1.18^{( \pm 0.07)} \mathrm{a}$ & $1.07^{( \pm 0.06)} \mathrm{a}$ & $0.18^{( \pm 0.04)} \mathrm{a}$ & $44.39^{( \pm 0.25)} \mathrm{a}$ & $3.24^{( \pm 0.99)} \mathrm{a}$ \\
\hline & NT12 & $1.06^{( \pm 0.12)} \mathrm{a}$ & $0.97^{( \pm 0.05)} \mathrm{a}$ & $0.20^{( \pm 0.05)} \mathrm{a}$ & $49.01^{( \pm 3.40)} \mathrm{a}$ & $3.25^{( \pm 0.13)} \mathrm{a}$ \\
\hline \multirow[t]{6}{*}{$7-17 \mathrm{~cm}$} & $\mathrm{CO}$ & $1.20^{( \pm 0.02)} \mathrm{c}$ & $1.21^{( \pm 0.15)} \mathrm{c}$ & $0.15^{( \pm 0.01)} \mathrm{a}$ & $42.01^{( \pm 3.63)} \mathrm{b}$ & $2.86^{( \pm 0.12)} a$ \\
\hline & C6 & $1.22^{( \pm 0.04)} \mathrm{c}$ & $1.66^{( \pm 0.39)} \mathrm{bc}$ & $0.15^{( \pm 0.01)} \mathrm{a}$ & $48.78^{( \pm 2.15)} \mathrm{a}$ & $3.02^{( \pm 0.52)} \mathrm{a}$ \\
\hline & $\mathrm{C} 12$ & $1.24^{( \pm 0.07)} \mathrm{bc}$ & $1.89^{( \pm 0.85)} \mathrm{abc}$ & $0.14^{( \pm 0.03)} \mathrm{ab}$ & $46.66^{( \pm 5.07)} \mathrm{ab}$ & $3.04^{( \pm 0.69)} \mathrm{a}$ \\
\hline & $\mathrm{C} 18$ & $1.34( \pm 0.03) \mathrm{ab}$ & $2.36^{( \pm 0.55)} \mathrm{abc}$ & $0.10^{( \pm 0.01)} \mathrm{ab}$ & $47.01^{( \pm 3.86)} \mathrm{ab}$ & $2.88^{( \pm 0.73)} a$ \\
\hline & $\mathrm{C} 24$ & $1.33^{( \pm 0.05)} \mathrm{ab}$ & $2.84^{( \pm 0.11)} \mathrm{ab}$ & $0.10^{( \pm 0.01)} \mathrm{ab}$ & $45.82^{( \pm 2.88)} \mathrm{ab}$ & $2.63^{( \pm 0.25)} \mathrm{a}$ \\
\hline & NT12 & $1.41^{( \pm 0.03)} \mathrm{a}$ & $3.12^{( \pm 0.58)} \mathrm{a}$ & $0.08^{( \pm 0.01)} \mathrm{b}$ & $51.11^{( \pm 6.90)} \mathrm{a}$ & $2.96^{( \pm 0.32)} \mathrm{a}$ \\
\hline \multirow[t]{6}{*}{$20-30 \mathrm{~cm}$} & $\mathrm{CO}$ & $1.34^{( \pm 0.03)} \mathrm{a}$ & $2.36^{( \pm 0.13)} \mathrm{a}$ & $0.06^{( \pm 0.01)} \mathrm{a}$ & $36.69^{( \pm 1.87)} \mathrm{a}$ & $2.35^{( \pm 0.39)} \mathrm{a}$ \\
\hline & C6 & $1.28^{( \pm 1.28)} \mathrm{a}$ & $2.31^{( \pm 0.36)} \mathrm{a}$ & $0.07^{( \pm 0.01)} \mathrm{a}$ & $37.54^{( \pm 2.90)} \mathrm{a}$ & $2.25^{( \pm 0.76)} \mathrm{a}$ \\
\hline & $\mathrm{C} 12$ & $1.35^{( \pm 0.02)} \mathrm{a}$ & $2.65^{( \pm 0.27)} \mathrm{a}$ & $0.05^{( \pm 0.01)} \mathrm{a}$ & $36.46^{( \pm 3.98)} \mathrm{a}$ & $2.08^{( \pm 0.53)} \mathrm{a}$ \\
\hline & $\mathrm{C} 18$ & $1.35^{( \pm 0.05)} \mathrm{a}$ & $3.19^{( \pm 0.67)} \mathrm{a}$ & $0.05^{( \pm 0.01)} \mathrm{a}$ & $34.09^{( \pm 3.50)} \mathrm{a}$ & $2.15^{( \pm 1.20)} \mathrm{a}$ \\
\hline & $\mathrm{C} 24$ & $1.35^{( \pm 0.04)} \mathrm{a}$ & $2.81^{( \pm 0.53)} \mathrm{a}$ & $0.07^{( \pm 0.02)} \mathrm{a}$ & $33.62^{( \pm 1.01)} \mathrm{a}$ & $2.08^{( \pm 0.27)} a$ \\
\hline & NT12 & $1.36^{( \pm 0.07)} \mathrm{a}$ & $2.65^{( \pm 0.65)} \mathrm{a}$ & $0.06^{( \pm 0.01)} \mathrm{a}$ & $38.13^{( \pm 1.38)} \mathrm{a}$ & $2.41^{( \pm 0.08)} \mathrm{a}$ \\
\hline
\end{tabular}

$\dagger$ C0, newly chiseled soil; C6, NT 6 months after chisel tillage; C12, NT 12 months after chisel tillage; C18, NT 18 months after chisel tillage; C24, NT 24 months

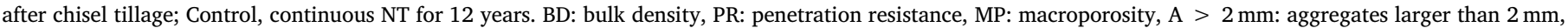

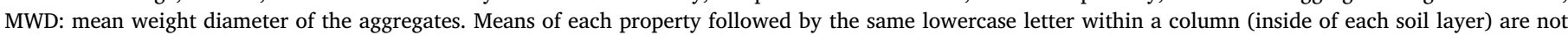
significantly different at $\alpha=0.05$ based on Tukey`s test. Note: Cited and adapted from Nunes et al. (2015b), as critical background information.

topsoil, but soil C sequestration response to NT is site-specific and divergent results have been shown. Powlson et al. (2016) conducted a meta-analysis, showing that increases on soil C stock due to the adoption of conservation agriculture practices (e.g., NT) can be minimal. Their conclusion was consistent with other results from 125 on-farm trials in Southern Africa (Cheesman et al., 2016). Govaerts et al. (2009) conducted a literature review and found that in 7 of the 78 cases withheld, the soil C stock was lower in NT compared to conventional tillage, in 40 cases it was higher, and in 31 cases it was neutral. According to Govaerts et al. (2009), the negative or neutral effect of NT on
C sequestration can also be linked to the shallower root growth in NT soils as compared to conventional tillage. Thus, by concentrating root system in the topsoil layer (Figs. 1 and 2), subsurface soil compaction can also decrease $\mathrm{C}$ sequestration, hence decreasing the potential benefits of NT adoption on mitigating climate change.

Nutrient content and soil physical properties in the surface layer did not affect root growth (Fig. 3 and Tables 7 and 6), suggesting that even the worst chemical and physical conditions already ensured full plant root growth. Thus, the continuous addition of high doses of fertilizer may not mean necessarily result in increased crop productivity but

Table 4

Means (standard errors) for soil chemical properties as a function of time after chisel tillage under no-till.

\begin{tabular}{|c|c|c|c|c|c|c|c|c|}
\hline Layer & Treatment $^{\dagger}$ & $\begin{array}{l}\text { SOC } \\
\%\end{array}$ & $\begin{array}{l}\mathrm{SOC}_{\mathrm{ESM}} \\
\mathrm{Mg} \mathrm{ha}^{-1}\end{array}$ & $\mathrm{pH}$ & $\mathrm{Al}$ & $\begin{array}{c}\mathrm{Ca} \\
-3\end{array}$ & $\mathrm{~K}$ & $\begin{array}{c}\mathrm{P} \\
-3\end{array}$ \\
\hline \multirow[t]{7}{*}{$0-7 \mathrm{~cm}$} & $\mathrm{CO}$ & $1.74^{( \pm 0.13)} \mathrm{a}$ & $13.54^{( \pm 1.04)} \mathrm{a}$ & $4.98^{( \pm 0.05)} \mathrm{a}$ & $13.93^{( \pm 0.95)} \mathrm{a}$ & $32.9^{( \pm 0.5)} \mathrm{a}$ & $185.5^{( \pm 45.8)} \mathrm{a}$ & $42.4^{( \pm 21.4)} \mathrm{a}$ \\
\hline & C6 & $1.96^{( \pm 0.19)} \mathrm{a}$ & $15.19^{( \pm 1.51)} \mathrm{a}$ & $5.15^{( \pm 0.10)} \mathrm{a}$ & $10.73^{( \pm 3.38)} \mathrm{a}$ & $36.9^{( \pm 4.8)} \mathrm{a}$ & $191.5^{( \pm 40.9)} \mathrm{a}$ & $53.7^{( \pm 8.4)} \mathrm{a}$ \\
\hline & $\mathrm{C} 12$ & $1.94^{( \pm 0.14)} \mathrm{a}$ & $14.05^{( \pm 1.12)} \mathrm{a}$ & $4.98^{( \pm 0.17)} \mathrm{a}$ & $12.63^{( \pm 0.84)} \mathrm{a}$ & $35.5^{( \pm 0.5)} \mathrm{a}$ & $174.0^{( \pm 57.5)} \mathrm{a}$ & $45.7^{( \pm 11.7)} a$ \\
\hline & $\mathrm{C} 18$ & $1.94^{( \pm 0.13)} \mathrm{a}$ & $15.08^{( \pm 1.04)} \mathrm{a}$ & $4.98^{( \pm 0.17)} \mathrm{a}$ & $12.88^{( \pm 1.43)} \mathrm{a}$ & $34.0^{( \pm 1.8)} \mathrm{a}$ & $171.0^{( \pm 35.5)} \mathrm{a}$ & $32.9^{( \pm 4.2)} \mathrm{a}$ \\
\hline & $\mathrm{C} 24$ & $1.85^{( \pm 0.14)} \mathrm{a}$ & $14.37^{( \pm 1.07)} \mathrm{a}$ & $5.25^{( \pm 0.06)} \mathrm{a}$ & $11.33^{( \pm 2.89)} \mathrm{a}$ & $34.6^{( \pm 3.7)} \mathrm{a}$ & $169.6^{( \pm 36.4)} \mathrm{a}$ & $29.2^{( \pm 8.1)} \mathrm{a}$ \\
\hline & NT12 & $1.99^{( \pm 0.06)} \mathrm{a}$ & $15.41^{( \pm 0.39)} \mathrm{a}$ & $5.00^{( \pm 0.34)} \mathrm{a}$ & $13.83^{( \pm 0.78)} \mathrm{a}$ & $31.6^{( \pm 2.1)} \mathrm{a}$ & $170.7^{( \pm 27.2)} \mathrm{a}$ & $39.3^{( \pm 13.8)} \mathrm{a}$ \\
\hline & Mean & $1.90^{( \pm 0.15)}$ & $14.61^{( \pm 1.03)}$ & $5.05^{( \pm 0.18)}$ & $12.31^{( \pm 2.89)}$ & $34.6^{( \pm 3.7)}$ & $179.0^{( \pm 44.4)}$ & $39.8^{( \pm 13.8)}$ \\
\hline \multirow[t]{7}{*}{$7-17 \mathrm{~cm}$} & $\mathrm{CO}$ & $1.29^{( \pm 0.01)} \mathrm{a}$ & $15.73^{( \pm 0.65)} \mathrm{a}$ & $5.23^{( \pm 0.10)} \mathrm{a}$ & $10.48^{( \pm 2.11)} \mathrm{a}$ & $34.4^{( \pm 2.2)} \mathrm{a}$ & $148.0^{( \pm 32.4)} \mathrm{a}$ & $12.3^{( \pm 7.8)} \mathrm{a}$ \\
\hline & $\mathrm{C} 6$ & $1.32^{( \pm 0.02)} \mathrm{a}$ & $15.90^{( \pm 0.90)} \mathrm{a}$ & $5.33^{( \pm 0.22)} \mathrm{a}$ & $8.85^{( \pm 3.34)} \mathrm{a}$ & $39.3^{( \pm 6.7)} \mathrm{a}$ & $134.0^{( \pm 44.6)} \mathrm{a}$ & $12.4^{( \pm 10.6)} \mathrm{a}$ \\
\hline & $\mathrm{C} 12$ & $1.24^{( \pm 0.02)} \mathrm{a}$ & $15.76^{( \pm 0.55)} \mathrm{a}$ & $5.30^{( \pm 0.12)} \mathrm{a}$ & $9.93^{( \pm 1.44)} \mathrm{a}$ & $36.1^{( \pm 2.1)} \mathrm{a}$ & $135.5^{( \pm 33.3)} \mathrm{a}$ & $12.9^{( \pm 5.4)} \mathrm{a}$ \\
\hline & C18 & $1.27^{( \pm 0.01)} \mathrm{a}$ & $15.75^{( \pm 0.42)} \mathrm{a}$ & $5.40^{( \pm 0.16)} \mathrm{a}$ & $9.60^{( \pm 1.19)} \mathrm{a}$ & $40.6^{( \pm 9.5)} \mathrm{a}$ & $117.0^{( \pm 28.2)} \mathrm{a}$ & $13.9^{( \pm 4.8)} \mathrm{a}$ \\
\hline & $\mathrm{C} 24$ & $1.26^{( \pm 0.01)} \mathrm{a}$ & $15.66^{( \pm 0.94)} \mathrm{a}$ & $5.45^{( \pm 0.13)} \mathrm{a}$ & $9.38^{( \pm 1.50)} \mathrm{a}$ & $39.0^{( \pm 5.1)} \mathrm{a}$ & $131.5^{( \pm 58.9)} \mathrm{a}$ & $16.3^{( \pm 11.3)} \mathrm{a}$ \\
\hline & NT12 & $1.24^{( \pm 0.03)} \mathrm{a}$ & $14.92^{( \pm 1.21)} \mathrm{a}$ & $5.40^{( \pm 0.08)} \mathrm{a}$ & $6.70^{( \pm 1.76)} \mathrm{a}$ & $39.9^{( \pm 4.1)} \mathrm{a}$ & $152.0^{( \pm 49.2)} \mathrm{a}$ & $10.3^{( \pm 5.4)} \mathrm{a}$ \\
\hline & Mean & $1.27^{( \pm 0.03)}$ & $15.62^{( \pm 0.78)}$ & $5.34^{( \pm 0.15)}$ & $9.38^{( \pm 1.94)}$ & $38.5^{( \pm 5.5)}$ & $134.2^{( \pm 39.9)}$ & $13.1^{( \pm 7.3)}$ \\
\hline \multirow[t]{7}{*}{$20-30 \mathrm{~cm}$} & $\mathrm{CO}$ & $1.21^{( \pm 0.07)} \mathrm{a}$ & $16.46^{( \pm 0.94)} \mathrm{a}$ & $5.33^{( \pm 0.13)} \mathrm{a}$ & $12.10^{( \pm 3.29)} \mathrm{a}$ & $30.4^{( \pm 5.9)} \mathrm{a}$ & $55.5^{( \pm 14.6)} \mathrm{a}$ & $2.2^{( \pm 0.8)} \mathrm{a}$ \\
\hline & C6 & $1.14^{( \pm 0.03)} \mathrm{a}$ & $15.50^{( \pm 0.34)} \mathrm{a}$ & $5.45^{( \pm 0.13)} \mathrm{a}$ & $8.53^{( \pm 3.31)} \mathrm{a}$ & $32.8^{( \pm 7.4)} \mathrm{a}$ & $87.0^{( \pm 51.3)} \mathrm{a}$ & $2.9^{( \pm 1.7)} \mathrm{a}$ \\
\hline & $\mathrm{C} 12$ & $1.13^{( \pm 0.04)} \mathrm{a}$ & $15.37^{( \pm 0.54)} \mathrm{a}$ & $5.30^{( \pm 0.08)} \mathrm{a}$ & $9.58^{( \pm 2.35)} \mathrm{a}$ & $31.3^{( \pm 2.6)} \mathrm{a}$ & $65.5^{( \pm 26.1)} \mathrm{a}$ & $2.4^{( \pm 1.5)} \mathrm{a}$ \\
\hline & C18 & $1.18^{( \pm 0.09)} \mathrm{a}$ & $16.05^{( \pm 1.21)} \mathrm{a}$ & $5.35^{( \pm 0.24)} \mathrm{a}$ & $8.48^{( \pm 1.95)} \mathrm{a}$ & $35.4^{( \pm 8.3)} \mathrm{a}$ & $50.5^{( \pm 17.2)} \mathrm{a}$ & $2.4^{( \pm 0.3)} \mathrm{a}$ \\
\hline & $\mathrm{C} 24$ & $1.21^{( \pm 0.03)} \mathrm{a}$ & $16.46^{( \pm 0.41)} \mathrm{a}$ & $5.40^{( \pm 0.08)} \mathrm{a}$ & $9.68^{( \pm 1.06)} \mathrm{a}$ & $29.6^{( \pm 2.8)} \mathrm{a}$ & $53.5^{( \pm 25.7)} \mathrm{a}$ & $2.4^{( \pm 0.6)} \mathrm{a}$ \\
\hline & NT12 & $1.17^{( \pm 0.12)} \mathrm{a}$ & $15.91^{( \pm 1.89)} \mathrm{a}$ & $5.33^{( \pm 0.15)} \mathrm{a}$ & $12.40^{( \pm 3.69)} \mathrm{a}$ & $31.5^{( \pm 7.2)} \mathrm{a}$ & $71.5^{( \pm 29.2)} \mathrm{a}$ & $2.5^{( \pm 1.1)} \mathrm{a}$ \\
\hline & Mean & $1.17^{( \pm 0.08)}$ & $15.96^{( \pm 0.89)}$ & $5.38^{( \pm 0.14)}$ & $9.38^{( \pm 2.59)}$ & $32.0^{( \pm 5.2)}$ & $62.4^{( \pm 29.6)}$ & $2.5^{(1.1)}$ \\
\hline
\end{tabular}

+ C0, newly chiseled soil; C6, NT 6 months after chisel tillage; C12, NT 12 months after chisel tillage; C18, NT 18 months after chisel tillage; C24, NT 24 months

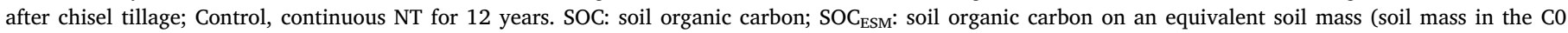

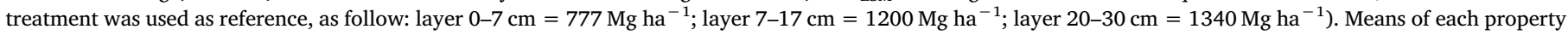

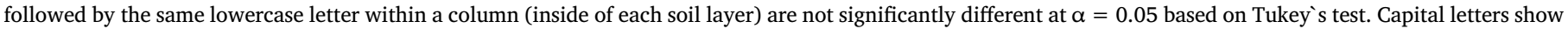
significance of overall treatments for layer. 

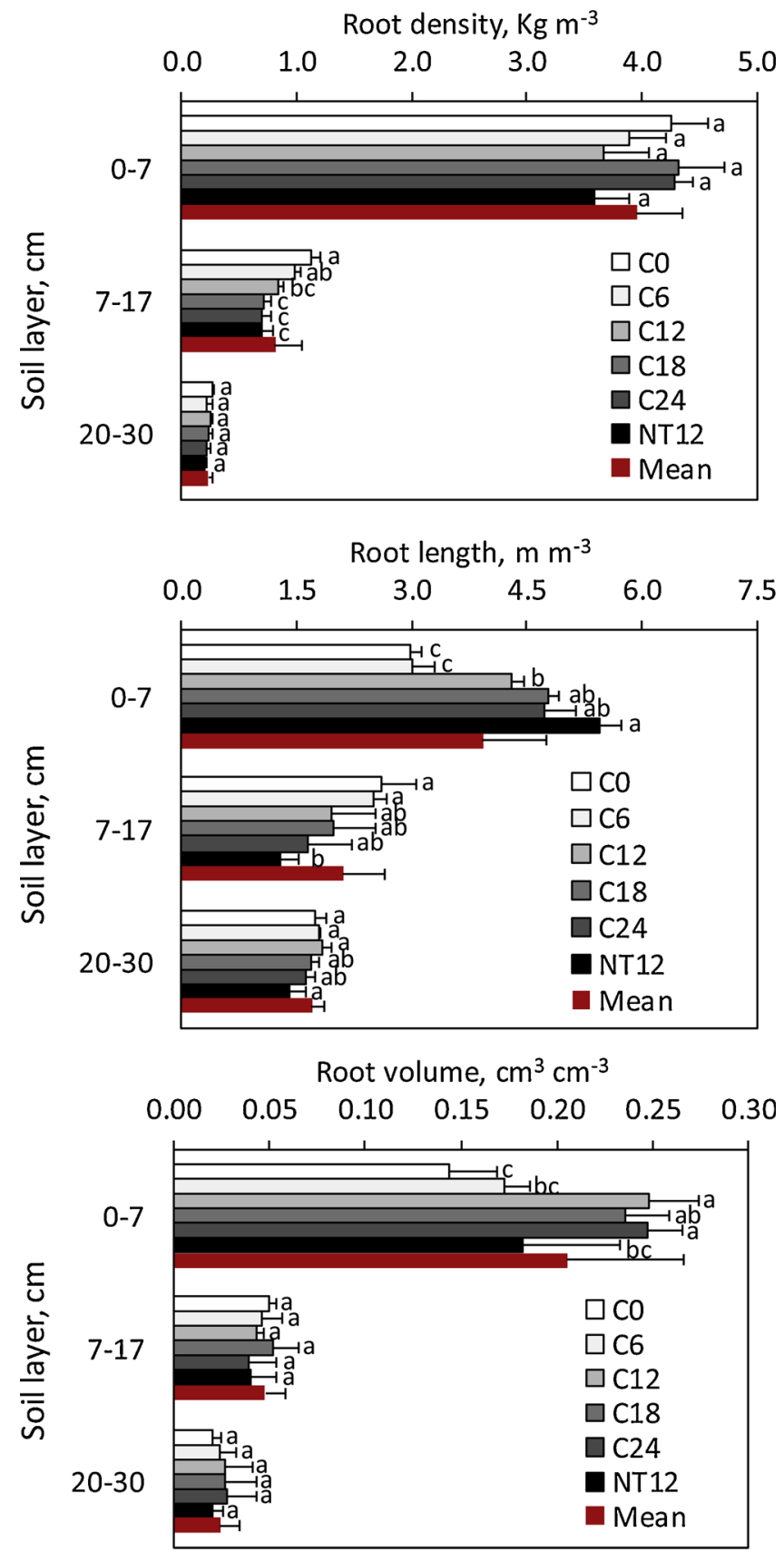

Fig. 2. Root density, root length density and root volume density of corn plants in a soil under no-till. C0, newly chiseled soil; C6, NT 6 months after chisel tillage; C12, NT 12 months after chisel tillage; C18, NT 18 months after chisel tillage; C24, NT 24 months after chisel tillage; Control, continuous NT for 12 years. Horizontal represent the standard deviation in relation to the average. Horizontal bars indicate standard deviation. The same lowercase letter (within each soil layer) are not significantly different at $\alpha=0.05$ based on Tukey`s test. Capital letters show significance of overall treatments for layer.

could be resulting in higher production costs and environmental contamination if excess fertilizers applied to the soil surface are carried away as runoff (Denardin et al., 2008). In contrast to the soil chemical indicators, strong correlation between root growth and soil physical attributes (PR, MP and $\mathrm{BD}$ ) as well as the multivariable regression results (Table 7) shows that among all soil factors (chemical, physical and OC) studied, soil compaction is the most limiting to plant root growth within the NT subsurface layers. Past studies also suggested that soil compaction has been concentrating crop roots in the first few centimeters of the soil profile under NT (Tormena et al., 1999; Reichert et al., 2009). To increase root growth below the surface layer, the first action is to mitigate soil compaction. In this study, improvement in soil physical conditions by chiseling or with fixed shanks attached to the seeder (Tables 1 and 3) increased root growth in the 7- to 17-cm soil layer (Figs. 1 and 2).

Increased PR and decreased MP both reduce root growth (Vepraskas, 1994; Bengough et al., 2011) because those soil properties are directly linked to aeration and other critical plant growth factors (Letey, 1985). In general, MP values of $0.10 \mathrm{~m}^{3} \mathrm{~m}^{-3}$ or less and PR values of $2 \mathrm{MPa}$ or greater are defined as being limiting to root growth (Tormena et al., 1999; Kay et al., 2006). Others such as Materechera and Mloza-Banda (1997) and Imhoff et al. (2010) have reported that root growth begins to decrease as PR approaches $1 \mathrm{MPa}$ and is severely limited when PR equals $3 \mathrm{MPa}$. In our study, the subsurface soil layer under NT had MP values $\leq 0.08 \mathrm{~m}^{3} \mathrm{~m}^{-3}$, indicating decreased oxygen availability and diffusion of heat in the soil, which both affect plant metabolic process and decrease root growth (Bennicelli et al., 1998; Ityel et al., 2014) were negatively impacted. High PR ( $>3 \mathrm{MPa}$ ) in the subsurface layer also decreases root elongation, as demonstrated by Clark et al. (2003) and Bengough et al. (2011). Therefore, we conclude that among all soil attributes studied, the BD [strongly correlated with MP and PR (Table 5)], MP and PR were the predominant soil properties limiting root growth in the NT subsurface soil layers (Tables 6 and 7).

Continuity and connectivity of bio-pores under NT system (Franchini et al., 2012) can result in greater gas flow within the soil (Carter, 1992). This may also enhance root growth into deeper layers, since bio-pores can provide an alternative pathway for growth. Morphological plasticity of cereal roots allows for growth in these narrow cracks (Liepic et al., 2012), even when PR values in the soil matrix are relatively high. However, in long-term NT soils managed without other conservations practices, bio-pores alone were not enough to promote root growth below 7-cm soil depth.

Overall, we conclude that soil compaction is the predominant factor limiting root growth in the subsurface soil layer under NT is supported by the multivariable correlation and regression analyses conducted with the combined dataset from the 0 to $30-\mathrm{cm}$ depth. In addition to the soil physical properties (MP, BD, and PR), P and OC content were also strongly correlated to root growth. Without question, OC is one of the most important constituents of the soil due to its capacity to affect plant growth as both a source of energy and a trigger for nutrient availability through mineralization. It is also the primary source of energy and nutrients for soil microorganisms and an important factor influencing aggregate stability as well as nutrient cycling and water holding capacity. OC also influences soil structure, increasing soil physical condition affecting movement of plant roots through the soil. Plant available P also affects root growth (Gabelman et al., 1986) since this nutrient is essential for several plants physiological process (Blevins, 1994). Therefore, reducing vertical stratification of OC and P can also improve root growth in subsurface soil layers within long-term NT fields.

This study also shows that assessments of soil conditions affecting crop growth under NT farming systems need to be improved. Currently, productivity is optimized based on soil fertility models that focus almost exclusively on soil chemical indicators (i.e., $\mathrm{pH}$ and nutrient concentrations), but neglect biological and physical indicators of soil health. Under NT, soil conditions affecting plant growth are a function of both soil structure created by the biota and delivery of nutrients from fertilizer and crop residues which enter through the soil surface. Soil structure which influences storage and availability of water, storage and diffusion of heat, oxygen flow, permeability to air, and resistance to root penetration significantly influences those processes. Thus, soil structure indicators, such as PR, MP, and BD along with biological indicators must be incorporated into current assessments of crop growth conditions under NT.

Incorporating soil physical and biological indicators is even more important when soil profiles are stratified (Tables 1-4) and root growth 

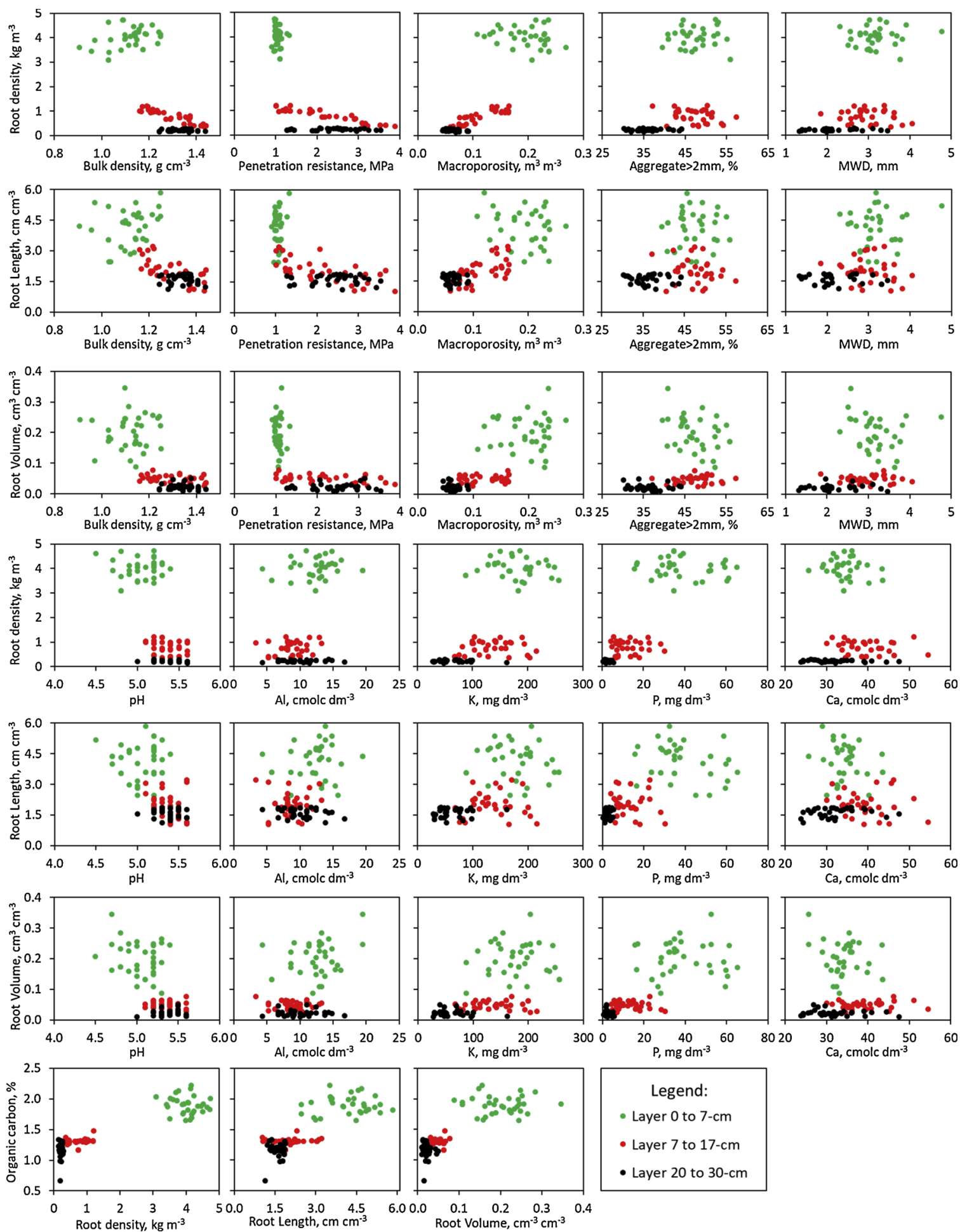

Fig. 3. Bivariate scatterplots between root growth indicator (root density, root length, and root volume) and physical and chemical attributes of soil.

is limited by soil physical conditions. In this case, traditional soil fertility assessment methods will just increase nutrient concentrations at or near the soil surface, often further aggravating stratification. The compacted layer interferes with hydrology, plant water and nutrient availability, air and heat diffusion, and both plant and root growth due to PR and the soil solution itself. Soil fertility under NT must therefore be interpreted based on biological and physical characteristics as well as chemical characteristics to know when a desirable soil condition has been created to promote crop growth and nutrient use efficiency. If soils are stratified, management practices such as the use of seeders equipped with fixed shanks to disrupt compact layers should be adopted. This type of seeder will not only disrupt compacted soil layers (Table 1) but also promote $\mathrm{P}$ uptake (Table 2) and stimulate root growth in those layers (Fig. 1; Su et al., 2015). Over time, this process can also increase OC concentration (Table 2) and, consequently, improve soil structure in subsurface layers $(7-$ to $17-\mathrm{cm})$ within long-term NT systems. 
Table 5

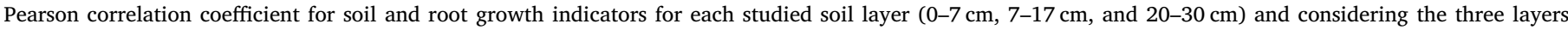
combined $(0-30 \mathrm{~cm})$.

\begin{tabular}{|c|c|c|c|c|c|c|c|c|c|c|c|c|c|}
\hline & $\mathrm{RD}^{\dagger}$ & $\mathrm{RL}$ & $\mathrm{RV}$ & $\mathrm{BD}$ & $\mathrm{RP}$ & MP & $\mathrm{A} 2 \mathrm{~mm}$ & MWD & SOC & $\mathrm{pH}$ & $\mathrm{Al}$ & K & $\mathrm{P}$ \\
\hline \multicolumn{14}{|c|}{0 to $7-\mathrm{cm}$} \\
\hline RL & 0.741 & & & & & & & & & & & & \\
\hline RV & 0.479 & 0.603 & & & & & & & & & & & \\
\hline $\mathrm{BD}$ & 0.449 & 0.474 & -0.071 & & & & & & & & & & \\
\hline $\mathrm{RP}$ & 0.121 & 0.306 & -0.120 & 0.695 & & & & & & & & & \\
\hline MP & -0.283 & -0.375 & 0.220 & -0.950 & -0.661 & & & & & & & & \\
\hline $\mathrm{A} 2 \mathrm{~mm}$ & -0.271 & -0.195 & -0.610 & 0.133 & -0.027 & -0.257 & & & & & & & \\
\hline MWD & -0.195 & -0.100 & -0.585 & 0.342 & 0.106 & -0.468 & 0.873 & & & & & & \\
\hline SOC & -0.413 & -0.150 & -0.395 & 0.257 & 0.097 & -0.428 & 0.585 & 0.563 & & & & & \\
\hline $\mathrm{pH}$ & -0.026 & -0.030 & -0.405 & 0.379 & -0.007 & -0.387 & 0.178 & 0.348 & 0.139 & & & & \\
\hline $\mathrm{Al}$ & 0.300 & 0.225 & 0.527 & -0.249 & 0.182 & 0.393 & -0.406 & -0.523 & 0.433 & -0.791 & & & \\
\hline $\mathrm{K}$ & -0.317 & -0.304 & 0.016 & -0.267 & -0.218 & 0.131 & -0.485 & -0.369 & 0.034 & -0.093 & -0.222 & & \\
\hline $\mathrm{P}$ & -0.212 & -0.412 & 0.129 & -0.635 & -0.330 & 0.609 & -0.318 & -0.376 & -0.172 & 0.614 & 0.551 & 0.359 & \\
\hline $\mathrm{Ca}$ & -0.317 & -0.274 & -0.513 & 0.186 & -0.273 & -0.344 & 0.429 & 0.521 & 0.441 & 0.734 & -0.989 & 0.230 & -0.484 \\
\hline \multicolumn{14}{|c|}{7 to $17-\mathrm{cm}$} \\
\hline $\mathrm{RL}$ & 0.921 & & & & & & & & & & & & \\
\hline RV & 0.608 & 0.756 & & & & & & & & & & & \\
\hline $\mathrm{BD}$ & -0.997 & -0.921 & -0.560 & & & & & & & & & & \\
\hline $\mathrm{RP}$ & -0.995 & -0.931 & -0.657 & 0.991 & & & & & & & & & \\
\hline MP & 0.989 & 0.898 & 0.548 & -0.994 & -0.979 & & & & & & & & \\
\hline $\mathrm{A} 2 \mathrm{~mm}$ & -0.719 & -0.619 & -0.153 & 0.725 & 0.680 & -0.710 & & & & & & & \\
\hline MWD & -0.357 & -0.405 & -0.173 & 0.335 & 0.324 & -0.332 & 0.512 & & & & & & \\
\hline SOC & 0.651 & 0.475 & 0.173 & -0.667 & -0.608 & 0.709 & -0.612 & -0.086 & & & & & \\
\hline $\mathrm{pH}$ & -0.603 & -0.615 & -0.475 & 0.607 & 0.624 & -0553 & 0.487 & 0.278 & -0.267 & & & & \\
\hline $\mathrm{Al}$ & 0.401 & 0.324 & 0.049 & -0.394 & -0.382 & 0.374 & -0.551 & -0.709 & 0.109 & -0.606 & & & \\
\hline $\mathrm{K}$ & -0.006 & -0.069 & -0.114 & 0.035 & -0.039 & -0.068 & 0.027 & 0.283 & -0.361 & -0.065 & -0.067 & & \\
\hline $\mathrm{P}$ & -0.021 & -0.161 & -0.364 & 0.008 & 0.032 & -0007 & -0.182 & 0.115 & -0.133 & 0.378 & -0.034 & 0.504 & \\
\hline $\mathrm{Ca}$ & -0.469 & -0.449 & -0.076 & 0.458 & 0.441 & -0.438 & 0.661 & 0.600 & -0.139 & 0.540 & -0.823 & 0.029 & 0.060 \\
\hline \multicolumn{14}{|c|}{20 to $30-\mathrm{cm}$} \\
\hline RL & 0.707 & & & & & & & & & & & & \\
\hline RV & 0.781 & 0.560 & & & & & & & & & & & \\
\hline $\mathrm{BD}$ & 0.079 & -0.253 & 0.022 & & & & & & & & & & \\
\hline $\mathrm{RP}$ & 0.129 & -0.008 & 0.178 & 0.427 & & & & & & & & & \\
\hline MP & -0.612 & -0.184 & -0.393 & -0.421 & -0.099 & & & & & & & & \\
\hline A $2 \mathrm{~mm}$ & -0.109 & -0.291 & -0.349 & 0.064 & -0.530 & 0.125 & & & & & & & \\
\hline MWD & 0.156 & -0.224 & -0.043 & 0.355 & -0.206 & -0.134 & 0.776 & & & & & & \\
\hline SOC & -0.203 & -0.161 & -0.245 & 0.309 & -0.107 & 0.014 & 0.140 & -0.021 & & & & & \\
\hline $\mathrm{pH}$ & -0.350 & -0.087 & 0.024 & -0.058 & -0.479 & 0.169 & -0.083 & -0.231 & 0.208 & & & & \\
\hline $\mathrm{Al}$ & 0.218 & -0.311 & 0.136 & 0.050 & 0.487 & -0.366 & -0.167 & 0.033 & -0.221 & -0.631 & & & \\
\hline K & -0.146 & 0.346 & -0.284 & -0.715 & -0.533 & 0.215 & 0.074 & -0.331 & -0.183 & 0.091 & -0415 & & \\
\hline $\mathrm{P}$ & -0.459 & 0.070 & -0.506 & -0.630 & -0.511 & 0.545 & 0.141 & -0.398 & 0.139 & 0.186 & -0.479 & 0.815 & \\
\hline $\mathrm{Ca}$ & -0.464 & 0.037 & -0.513 & -0.059 & -0.161 & 0.704 & 0.323 & 0.078 & 0.176 & 0.033 & -0.654 & 0.335 & 0.592 \\
\hline \multicolumn{14}{|c|}{0 to $30-\mathrm{cm}$} \\
\hline RL & 0.997 & & & & & & & & & & & & \\
\hline RV & 0.998 & 0.996 & & & & & & & & & & & \\
\hline $\mathrm{BD}$ & -0.991 & -0.985 & -0.987 & & & & & & & & & & \\
\hline $\mathrm{RP}$ & -0.984 & -0.982 & -0.978 & 0.989 & & & & & & & & & \\
\hline MP & 0.990 & 0.983 & 0.984 & -0.996 & -0.984 & & & & & & & & \\
\hline $\mathrm{A} 2 \mathrm{~mm}$ & 0.733 & 0.719 & 0.709 & -0.720 & -0.722 & 0.771 & & & & & & & \\
\hline MWD & 0.765 & 0.753 & 0.742 & -0.745 & -0.756 & 0.789 & 0.964 & & & & & & \\
\hline SOC & 0.997 & 0.992 & 0.992 & -0.985 & -0.979 & 0.989 & 0.769 & 0.797 & & & & & \\
\hline $\mathrm{pH}$ & -0.964 & -0.956 & -0.968 & 0.948 & 0.919 & -0.947 & -0.679 & -0.707 & -0.956 & & & & \\
\hline $\mathrm{Al}$ & 0.792 & 0.784 & 0.806 & -0.787 & -0.748 & 0.753 & 0.308 & 0.351 & 0.758 & -0.877 & & & \\
\hline K & 0.932 & 0.922 & 0.921 & -0.929 & -0.923 & 0.947 & 0.845 & 0.848 & 0.944 & -0.882 & 0.592 & & \\
\hline $\mathrm{P}$ & 0.990 & 0.979 & 0.986 & -0.987 & -0.971 & 0.989 & 0.748 & 0.776 & 0.989 & -0.962 & 0.785 & 0.948 & \\
\hline $\mathrm{Ca}$ & -0.286 & -0.291 & -0.311 & 0.279 & 0.259 & -0.214 & 0.332 & 0.250 & -0.232 & 0.371 & -0.744 & -0.007 & -0.258 \\
\hline
\end{tabular}

$\uparrow$ RD: root density, RL: root length density, RV: root volume density, BD: bulk density, PR: penetration resistance, MP: acroporosity, A > 2 mm: aggregates larger than $2 \mathrm{~mm}$, MWD: mean weight diameter of the aggregates, SOC: soil organic carbon. The highest ( $\geq 0.65)$ Pearson coefficient are bolded.

\section{Conclusions}

This study focused on crop root and soil property responses in the soil profiles beneath long-term no-till production systems in Brazil. We found definite stratification of soil physical, chemical and biological attributes. Soil nutrients (primarily $\mathrm{P}$ and $\mathrm{K}$ ) and soil organic carbon were concentrated in the surface 0 to $7-\mathrm{cm}$ layer. In contrast, subsurface layers had a high degree of compaction that resulted in a concentration of the root system in the surface $7-\mathrm{cm}$. Low oxygen availability and high penetration resistance, low organic carbon and low $\mathrm{P}$ concentrations in the subsurface layers appear to be the most limiting factors to deep plant root growth under no-till. Based on these results we strongly recommend that in addition to soil chemical measurements, physical and biological indicators also need to be considered when assessing soil quality/soil health for no-till crop productivity. 
Table 6

Cannonical correlation analysis and stimated cannonical coefficients of the root growth (Group I) and physical and chemical soil attributies (Group II) inside of each soil layer $(0-7 \mathrm{~cm}, 7-17 \mathrm{~cm}$, and $20-30 \mathrm{~cm})$ and, considering the three layer combined $(0-30 \mathrm{~cm})$.

\begin{tabular}{|c|c|c|c|c|c|c|c|c|c|c|c|c|}
\hline \multirow[t]{3}{*}{ Variable } & \multicolumn{3}{|c|}{ Layer 0 to $7-\mathrm{cm}$} & \multicolumn{3}{|c|}{ Layer 7- to $17-\mathrm{cm}$} & \multicolumn{3}{|c|}{ Layer 20 - to $30-\mathrm{cm}$} & \multicolumn{3}{|c|}{ Layer 0 to $30-\mathrm{cm}$} \\
\hline & \multicolumn{3}{|c|}{ Canonical pair } & \multicolumn{3}{|c|}{ Canonical pair } & \multicolumn{3}{|c|}{ Canonical pair } & \multicolumn{3}{|c|}{ Canonical pair } \\
\hline & First & Second & Third & First & Second & Third & First & Second & Third & First & Second & Third \\
\hline & \multicolumn{3}{|c|}{ - Group I: Root growth } & \multicolumn{3}{|c|}{ - Group I: Root growth -} & \multicolumn{3}{|c|}{- Group I: Root growth } & \multicolumn{3}{|c|}{ Group I: Root growth } \\
\hline $\mathrm{RD}^{\dagger}$ & -0.909 & 0.482 & 0.478 & 0.954 & -0.016 & 0.853 & 1.123 & -0.873 & 0.057 & 0.954 & -0.161 & 2.854 \\
\hline $\mathrm{RL}$ & 0.441 & 0.582 & -0.990 & 0.038 & -0.630 & -1.233 & -1.206 & -0.424 & 0.103 & 0.086 & -2.069 & -1.448 \\
\hline \multirow[t]{2}{*}{ RV } & -0.587 & -0.910 & -0.260 & 0.061 & 1.136 & -0.088 & -0.120 & 0.768 & 0.920 & 0.133 & 2.158 & -1.652 \\
\hline & \multicolumn{3}{|c|}{ Group II: Soil } & \multicolumn{3}{|c|}{$\longrightarrow$ Group II: Soil } & \multicolumn{3}{|c|}{$\longrightarrow$ Group II: Soil } & \multicolumn{3}{|c|}{$\longrightarrow$ Group II: Soil } \\
\hline $\mathrm{BD}$ & -0.858 & 0.041 & 0.342 & -0.358 & 0.713 & 0.982 & 0.435 & 0.409 & -0.884 & -0.115 & 1.228 & -0.713 \\
\hline $\mathrm{RP}$ & 0.922 & -0.116 & -0.011 & -0.726 & -2.128 & -0.738 & -0.250 & -0.171 & 0.771 & -0.130 & 0.545 & -0.026 \\
\hline MP & 0.064 & -0.718 & 0.304 & -0.083 & -1.364 & -0.007 & 0.084 & 0.682 & -0.515 & 0.270 & 1.200 & -1.095 \\
\hline$A>2 \mathrm{~mm}$ & 0.224 & 0.848 & 0.779 & 0.016 & 0.315 & -0.396 & 0.284 & -0.385 & 0.267 & -0.059 & -0.480 & 0.592 \\
\hline MWD & 0.014 & -0.019 & -0.414 & -0.049 & 0.153 & 0.590 & 0.168 & 0.191 & 0.003 & 0.034 & -0.106 & 0.063 \\
\hline SOC & 0.292 & -0.411 & -0.586 & 0.074 & 0.011 & 0.484 & -0.141 & -0.146 & 0.033 & 0.582 & -0.509 & -0.458 \\
\hline $\mathrm{pH}$ & 0.033 & 0.694 & 0.217 & 0.095 & 0.048 & 0.550 & -0.287 & 0.880 & 0.293 & -0.050 & -0.244 & 0.649 \\
\hline $\mathrm{Al}$ & -0.504 & 0.238 & 0.231 & 0.008 & 0.106 & 0.850 & 0.251 & 0.755 & -0.548 & 0.067 & 0.229 & -0.228 \\
\hline K & -0.032 & 0.362 & 0.144 & 0.015 & -0.497 & 0.120 & -0.391 & -0.028 & -0.343 & 0.050 & 0.003 & -0.568 \\
\hline$P$ & 0.090 & -0.152 & 0.750 & -0.035 & 0.014 & 0.017 & 0.304 & 0.115 & -0.514 & 0.114 & 0.949 & 1.653 \\
\hline $\mathrm{Ca}$ & 0.112 & -0.460 & 0.721 & -0.043 & 0.300 & 0.209 & -0.712 & 0.001 & -0.160 & -0.037 & 0.178 & -0.089 \\
\hline Corr & 0.732 & 0.504 & 0.378 & 0.968 & 0.623 & 0.390 & 0.727 & 0.548 & 0.322 & 0.957 & 0.324 & 0.190 \\
\hline Prop Expl & 69.525 & 20.594 & 9.98 & 94.766 & 4.078 & 1.157 & 67.365 & 25.681 & 6.954 & 98.613 & 1.052 & 0.335 \\
\hline$p$-value & 0.469 & 0.910 & 0.898 & $<0.001$ & 0.596 & 0.874 & 0.463 & 0.890 & 0.964 & $<0.001$ & 0.795 & 0.933 \\
\hline FD & 33 & 20 & 9 & 33 & 20 & 9 & 33 & 22 & 9 & 33 & 22 & 9 \\
\hline
\end{tabular}

' RD: root density, RL: root length density, RV: root volume density, BD: bulk density, PR: penetration resistance, MP: acroporosity, A > 2 mm: aggregates larger than $2 \mathrm{~mm}$, MWD: mean weight diameter of the aggregates, SOC: soil organic carbon, Corr: canonical correlation, Prop Expl: proportion of covariance explained by each canonical pair, and FD: freedon degree.

Table 7

Multiple regression, with stepwise elimination of explanatory variables, to obtain linear expressions for the prediction of the three indicators of root growth from the soil attributes of the two sampled soils under no-till.

\begin{tabular}{|c|c|c|c|}
\hline Equation & $\mathrm{R}^{2}$ & Adj. $\mathrm{R}^{2}$ & $p$-value \\
\hline \multicolumn{4}{|l|}{ Layer $7-$ to $17-\mathrm{cm}$} \\
\hline Root density $=2.516-0.189_{\mathrm{RP}}-1.010_{\mathrm{BD}}$ & 0.917 & 0.912 & $<0.001$ \\
\hline Root length $=7.0478-3.8544_{\mathrm{BD}}$ & 0.414 & 0.400 & $<0.001$ \\
\hline Root volume $=0.1068-0.0135_{\mathrm{RP}}-0.2374_{\mathrm{MP}}$ & 0.285 & 0.242 & 0.004 \\
\hline \multicolumn{4}{|l|}{ Layer $0-$ to $30-\mathrm{cm}$} \\
\hline Root density $=-2.8371+2.8397_{\mathrm{sOC}}+4.4495_{\mathrm{MP}}-0.2508_{\mathrm{RP}}+0.0152_{\mathrm{P}}$ & 0.904 & 0.901 & $<0.001$ \\
\hline Root length $=-4.7020+2.1657_{\mathrm{soc}}-0.2630_{\mathrm{RP}}+3.1853_{\mathrm{MP}}$ & 0.744 & 0.737 & $<0.001$ \\
\hline Root volume $=-0.1596+0.1347_{\mathrm{soc}}+0.3314_{\mathrm{MP}}+0.0007_{\mathrm{p}}$ & 0.783 & 0.777 & $<0.001$ \\
\hline
\end{tabular}

The stepwise regression started with: SOC, BD, RP and MP (layer 7-17 cm); and SOC, MP, RP, BD, P, K, A > 2 mm and MWD (layer 0-30 cm). These soil indicators were the most imporant in the canonical correlations and in the pesrson correlation.

\section{Acknowledgments}

To the São Paulo Research Foundation (FAPESP - Process number2015/12934-3), to the Brazilian Research Council (CNPq) and to the Brazilian Federal Agency for Support and Evaluation of Graduate Education (CAPES) for the scholarships and funding.

\section{Appendix A. Supplementary data}

Supplementary material related to this article can be found, in the online version, at doi:https://doi.org/10.1016/j.agee.2019.106607.

\section{References}

Andrews, S.S., Carroll, C.R., 2001. Designing a soil quality assessment tool for sustainable agroecosystem management. Ecol. Appl. 11, 1573-1585. https://doi.org/10.2307/ 3061079 .

Baker, J.M., Ochsner, T.E., Venterea, R.T., Griffis, T.J., 2007. Tillage and soil carbon sequestration-what do we really know? Agric. Ecosyst. Environ. 118, 1-5. https:// doi.org/10.1016/j.agee.2006.05.014.

Baligar, V.C., Fageria, N.K., Elrashidi, M., 1998. Toxicity and nutrient constraints on root growth. Hort Sci. 33, 960-965.

Barber, S.A., 1995. Soil Nutrient Bioavailability: A Mechanistic Approach, 2nd edn. John Wiley and Sons, New York.

Baumhardt, R.L., Stewart, B.A., Sainju, U.M., 2015. North American soil degradation: processes, practices, and mitigating strategies. Sustain. For. 7, 2936-2960.

Bengough, A.G., McKenzie, B., Hallett, M., Valentine, P.D., 2011. Root elongation, water stress, and mechanical impedance: a review of limiting stresses and beneficial root tip traits. J. Exp. Bot. 62, 59-68. https://doi.org/10.1093/jxb/erq350.

Bennicelli, R.P., Stepniewski, W., Zakrzhevsky, D.A., Balakhnina, T.I., Stepniewskaa, Z., Lipiec, J., 1998. The effect of soil aeration on superoxide dismutase activity, malondialdehyde level, pigment content and stomatal diffusive resistance in maize seedlings. Environ. Exp. Bot. 39, 203-211. https://doi.org/10.1016/S0098-8472(97) 00044-0.

Blevins, D.G., 1994. Uptake, translocation, and function of essential mineral elements in crop plants. In: Peterson, G.A. (Ed.), Physiology and Determination of Crop Yield. ASA, CSSA, and SSSA, Madison, WI, pp. 259-275.

Bohm, W., 1979. Methods of Studying Root Systems. Springer-Verlag, New York.

Bottinelli, N., Angers, D.A., Hallaire, V., Michot, D., Le Guillou, C., Cluzeau, D., Heddadj, D., Menasseri-Aubry, S., 2017. Tillage and fertilization practices affect soil aggregate stability in a Humic Cambisol of Northwest France. Soil Tillage Res. 170, 14-17. https://doi.org/10.1016/j.still.2017.02.008.

Carter, M.R., 1992. Characterizing of soil physical condition in reduced tillage systems for winter wheat on a fine sandy loam using small cores. Can. J. Soil Sc. 72, 395-402. https://doi.org/10.4141/cjss92-033.

Cheesman, S., Thierfelder, C., Eash, N.S., Kassie, G.T., Frossard, E., 2016. Soil carbon 
stocks in conservation agriculture systems of Southern Africa. Soil Tillage Res. 156, 99-109.

Clark, L.J., Whalley, W.R., Barraclough, P.B., 2003. How do roots penetrate strong soil? Plant Soil 255, 93-104.

Dairon, R., Dutertre, A., Tournebize, J., Marks-Perreau, J., Carluer, N., 2017. Long-term impact of reduced tillage on water and pesticide flow in a drained context. Environ. Sci. Pollut. Res. 24, 6866-6877. https://doi.org/10.1007/s11356-016-8123-x.

Dang, Y.P., Seymour, N.P., Walker, S.R., Bell, M.J., Freebairn, D.M., 2015. Strategic tillage in no-till farming systems in Australia's northern grains-growing regions: I. Drivers and implementation. Soil Tillage Res. 152, 104-114. https://doi.org/10. 1016/j.still.2015.03.009.

Denardin, J.E., Kochhann, R.A., Faganello, A., Sattler, A., Manhago, D.D., 2008. Vertical mulching" como prática conservacionista para manejo de enxurrada em sistema plantio direto. Rev. Bras. Ci. Solo 32, 2847-2852. https://doi.org/10.1590/S010006832008000700031.

Deubel, A., Hofmann, B., Orzessek, D., 2011. Long-term effects of tillage on stratification and plant availability of phosphate and potassium in a loess chernozem. Soil Tillage Res. 117, 85-92. https://doi.org/10.1016/j.still.2011.09.001.

Donagema, G.K., Campos, D.V.B., Calderano, S.B., Teixeira, W.G., Viana, J.H.M., 2011. Manual de Métodos de Análise de Solo, second ed. Embrapa Solos, Rio de Janeiro.

Eghball, B., Settimi, J.R., Maranville, J.W., Parkhurst, A.M., 1993. Fractal analysis for morphological description of corn roots under nitrogen stress. Agron. J. 85, 287-289. https://doi.org/10.2134/agronj1993.00021962008500020023x.

Ellert, B.H., Bettany, J.R., 1995. Calculation of organic matter and nutrients stored in soils under contrasting management regimes. Can. J. Soil Sc. 75, 529-538. https://doi. org/10.4141/cjss95-075.

Fageria, N.K., Moreira, A., 2011. The role of mineral nutrition on root growth of crop plants. Adv. Agron. 110, 251-331.

FAO - World Reference Base for Soil Resources, 2014. International soil classification system for naming soils and creating legends for soil maps. World Soil Resources Reports No. 106. FAO - World Reference Base for Soil Resources, Rome, Italy.

Franchini, J.C., Debiasi, H., Balbinot, A.A., Tonon, B.C., Farias, J.R.B., Oliveira, M.C.N., Torres, E., 2012. Evolution of crop yields in different tillage and cropping systems over two decades in southern Brazil. Field Crops Res. 137, 178-185. https://doi.org/ 10.1016/j.fcr.2012.09.003.

Gabelman, W.H., Gerloff, G.C., Schettini, T., Coltman, R., 1986. Genetic variability in root systems associated with nutrient acquisition and use. Hort Science 21, 971-973. https://doi.org/10.1080/01904160600564378.

Govaerts, B., Verhulst, N., Castellanos-Navarrete, A., Sayre, K.D., Dixon, J., Dendooven, L., 2009. Conservation agriculture and soil carbon sequestration: between myth and farmer reality. Crit. Rev. Plant Sci. 28, 97-122.

Grossman, R.B., Reinsch, T.G., 2002. Bulk density and linear extensibility. In: Dane, J.H., Topp, G.C. (Eds.), Eds.), Methods of Soil Analysis. Soil Science Society of America, Madison, Wisconsin, USA, pp. 207-210.

Grzesiak, S., Grzesiak, M.T., Hura, T., Marcinska, I., Rzepka, A., 2012. Changes in root system structure, leaf matric potential and gas exchange of maize and triticale seedlings affected by soil compaction. Environ. Exp. Bot. 88, 2-10. https://doi.org/ 10.1016/j.envexpbot.2012.01.010.

Hamza, M.A., Anderson, W.K., 2005. Soil compaction in cropping systems: a review of the nature, causes and possible solutions. Soil Tillage Res. 82, 121-145. https://doi.org/ 10.1016/j.still.2004.08.009.

Hoad, S.P., Russell, G., Lucas, M.E., Bingham, I.J., 2001. The management of wheat, barley, and oat root systems. Adv. Agron. 74, 193-246.

Horn, R., Peth, S., 2009. Soil structure formation and management effects on gas emission. Biologia 64, 449-453.

Houx, J.H., Wiebold, W.J., Fritschi, F.B., 2011. Long-term tillage and crop rotation determines the mineral nutrient distributions of some elements in a Vertic Epiaqualf. Soil Tillage Res. 112, 27-35. https://doi.org/10.1016/j.still.2010.11.003.

Imhoff, S., Kay, B.D., Silva, A.P., Hajabbasi, M.A., 2010. Evaluating responses of maize (Zea mays L.) to soil physical conditions using a boundary line approach. Soil Tillage Res. 106, 303-310. https://doi.org/10.1016/j.still.2009.11.007.

Ityel, E., Ben-Gal, A., Silberbusha, M., Lazarovitch, N., 2014. Increased root zone oxygen by a capillary barrier is beneficial to bell pepper irrigated with brackish water in an arid region. Agric. Water Manag. 131, 108-114. https://doi.org/10.1016/j.agwat. 2013.09.018.

Jorge, L.A.C., Rodrigues, A.F.O., 2008. Safira: sistema de análise de fibras e raízes. São Carlos: Embrapa Instrumentação Agropecuária, 21p. (Embrapa Instrumentação Agropecuária. Boletim de pesquisa e desenvolvimento, 24).Safira: sistema de análise de fibras e raízes. São Carlos: Embrapa Instrumentação Agropecuária, 21p. (Embrapa Instrumentação Agropecuária. Boletim de pesquisa e desenvolvimento, 24).

Karathanasis, A.D., Wells, K.L., 1990. Conservation tillage effects on the potassium status of some Kentucky soils. Soil Sci. Soc. Am. J. 4, 800-806. https://doi.org/10.2136/ sssaj1990.03615995005400030030x.

Karlen, D.L., Ditzler, C.A., Andrews, S.S., 2003. Soil quality: why and how? Geoderma 114, 145-156. https://doi.org/10.1016/S0016-7061(03)00039-9.

Karlen, D.L., Mausbach, M.J., Doran, J.W., Cline, R.G., Harris, R.F., Schuman, G.E., 1997. Soil quality: a concept, definition, and framework for evaluation (A guest editorial). Soil Sci. Soc. Am. J. 61, 4-10. https://doi.org/10.2136/sssaj1997. $03615995006100010001 x$.

Kassam, A., Friedrich, T., Derpsch, R., Kienzle, J., 2015. Overview of the Worldwide Spread of Conservation Agriculture. Field Actions Science Reports, pp. 8.
Kay, B.D., Hajabbasi, M.A., Ying, J., Tollenaar, M., 2006. Optimum versus non-limiting water contents for root growth, biomass accumulation, gas exchange and the rate of development of maize (Zea mays L.). Soil Tillage Res. 88, 42-54. https://doi.org/10. 1016/j.still.2005.04.005.

Kemper, W.D., Rosenau, R.C., 1986. Aggregate stability and size distribution. Methods of Soil Analysis, Part 1. Physical and Mineralogical Methods. Agronomy Monograph No. 9, 2nd edn. American Society of Agronomy, Madison, WI, USA, pp. 425-444.

Kinoshita, R., Schindelbeck, R.R., van Es, H.M., 2017. Quantitative soil profile-scale assessment of the sustainability of long-term maize residue and tillage management. Soil Tillage Res. 174, 34-44. https://doi.org/10.1016/j.still.2017.05.010.

Letey, J., 1985. Relationship between soil physical properties and crop production. Adv. Soil Sci. 1, 277-294.

Lipiec, J., Horn, R., Pietrusiewicz, J., Siczek, A., 2012. Effects of soil compaction on root elongation and anatomy of different cereal plant species. Soil Tillage Res. 121, 74-81. https://doi.org/10.1016/j.still.2012.01.013.

Luo, Z., Wang, E., Sun, O.J., 2010. Can no-tillage stimulate carbon sequestration in agricultural soils? A meta-analysis of paired experiments. Agric. Ecosystem Environ. 139, 224-231. https://doi.org/10.1016/j.agee.2010.08.006.

Magdoff, F.R., van Es, H.M., 2009. Building Soils for Better Crops: Sustainable Soil Management. Handbook Series Book 10. Sustainable Agriculture Research and Education, Waldorf, MD.

Manly, B.J.F., 2005. Multivariate Statistical Methods: A Primer, 3rd edn. Chapman and Hall, CRC, Taylor and Francis Group.

Materechera, S.A., Mloza-Banda, H.R., 1997. Soil penetration resistance, root growth and yield of maize as influenced by tillage system on ridges in Malawi. Soil Tillage Res. 41, 13-24. https://doi.org/10.1016/S0167-1987(96)01086-0.

Moebius-Clune, B.N., Moebius-Clune, D.J., Gugino, B.K., Idowu, O.J., Schindelbeck, R.R., Ristow, A.J., van Es, H.M., This, J.E., Shayler, H.A., McBride, M.B., Kurtz, K.S.M., Wolfe, D.W., Abawi, G.S., 2016. Comprehensive Assessment of Soil Health, 3th edition.

Nash, P.R., Nelson, K.A., Motavalli, P.P., 2013. Corn yield response to timing of strip tillage and nitrogen source applications. Agron. J. 105, 623-630. https://doi.org/10 2134/agronj2012.0338.

Nunes, M.R., Denardin, J.E., Pauletto, E.A., Faganello, A., Pinto, L.F.S., 2015a. Mitigation of clayey soil compaction managed under no-tillage. Soil Tillage Res. 148, 119-126. https://doi.org/10.1016/j.still.2014.12.007.

Nunes, M.R., Denardin, J.E., Pauletto, E.A., Faganello, A., Pinto, L.F.S., 2015b. Effect of soil chiseling on soil structure and root growth for a clayey soil under no-tillage. Geoderma 259-260, 149-155. https://doi.org/10.1016/j.geoderma.2015.06.003.

Nunes, M.R., Silva, A.P., Denardin, J.E., Giarola, N.F.B., Vaz, C.M.P., van Es, H.M., Silva, A.R., 2017. Soil chemical management drives structural degradation of Oxisols under a no-till cropping system. Soil Res. 55, 819-883. https://doi.org/10.1071/SR17063.

Nunes, M.R., van Es, H.M., Schindelbeck, R., Ristow, A.J., Ryan, M., 2018. No-till and cropping system diversication improve soil health and crop yield. Geoderma 328, 30-43. https://doi.org/10.1016/j.geoderma.2018.04.031.

Powlson, D.S., Stirling, C.M., Thierfelder, C., White, R.P., Jat, M.L., 2016. Does conservation agriculture deliver climate change mitigation through soil carbon sequestration in tropical agro-ecosystems? Agric. Ecosyst. Environ. 220, 164-174.

R Core Team, 2016. R: a Language and Environment for Statistical Computing. Available at. R Foundation for Statistical Computing, Vienna, Austria. http://www.R-project. org/.

Reichert, J.M., Suzuki, L.E.A.S., Reinert, D.J., Horn, R., Hakansson, I., 2009. Reference bulk density and critical degree-of-compactness for no-till crop production in subtropical highly weathered soils. Soil Tillage Res. 102, 242-254. https://doi.org/10. 1016/j.still.2008.07.002

Santos, H.G., Jacomine, P.K.T., Anjos, L.H., Oliveira, V.A., Oliveira, J.B., Coelho, M.R., Lumbreras, J.F., Cunha, T.J.F., 2006. Sistema Brasileiro de Classificação de solos, 2.ed. Embrapa Solos, Rio de Janeiro-RJ 306.

Scopel, E., Triomphe, B., Affholder, F., Silva, F.A.M., Corbeels, M., Xavier, J.H.V., Lahmar, R., Recous, S., Bernoux, M., Blanchart, E., Mendes, I.C., Tourdonnetric, S., 2013. Conservation agriculture cropping systems in temperate and tropical conditions, performances and impacts. A review. Agron. Sustain. Dev. 33, 113-130. https://doi. org/10.1007/s13593-012-0106-9.

Selles, F., Kochhann, R.A., Denardin, J.E., Zenter, R.P., Faganello, A., 1997. Distribution of phosphorus fractions in a Brazilian Oxisol under different tillage systems. Soil Tillage Res. 44, 23-34. https://doi.org/10.1016/S0167-1987(97)00026-3.

Sharma, P., Singh, G., Singh, R.P., 2013. Conservation tillage and optimal water supply enhances microbial enzyme (glucosidase, urease and phosphatase) activities in fields under wheat cultivation during various nitrogen management practices. Arch. Agron. Soil Sci. 59, 911-928. https://doi.org/10.1080/03650340.2012.690143.

Silva, A.P., Babujia, L.C., Franchini, J.C., Ralisch, R., Hungria, M., Guimarães, M.F., 2014b. Soil structure and its influence on microbial biomass in different soil and crop management systems. Soil Till. Res. 142, 42-53. https://doi.org/10.1016/j.still. 2014.04.006.

Silva, A.P., Ball, B.B., Tormena, C.A., Giarola, N.F.B., Guimarães, R.M.L., 2014a. Soil structure and greenhouse gas production differences between row and interrow. Sci. Agric. 71, 157-162. https://doi.org/10.1590/S0103-90162014000200011.

Singh, D.K., Sale, P.W.G., Routley, R.R., 2005. Increasing phosphorus supply in subsurface soil in northern Australia: rationale for deep placement and the effects with various crops. Plant Soil 269, 35-44. https://doi.org/10.1007/s11104-004-2475-6.

Su, W., Liu, B., Liuc, X., Li, X., Rena, T., Conga, R., Lu, J., 2015. Effect of depth of fertilizer 
banded-placement on growth, nutrient uptake and yield of oilseed rape (Brassica napus L.). Eur. J. Agron. 62, 38-45. https://doi.org/10.1016/j.eja.2014.09.002.

Suzuki, L.E.A.S., Reichert, J.M., Reinert, D.J., 2013. Degree of compactness, soil physical properties and yield of soybean in six soils under no-tillage. Soil Res. 51, 311-321. https://doi.org/10.1071/SR12306.

Tedesco, M.J., Gianello, C., Bissani, C.A., Bohnen, H., Volkweiss, S.J., 1995. Análise de solo, plantas e outros materiais, 2a ed. UFRGS, Porto Alegre.

Tormena, C.A., Silva, A.P., Libardi, P.L., 1999. Soil physical quality of a Brazilian Oxisol under two tillage systems using the least limiting water range approach. Soil Tillage Res. 52, 223-232. https://doi.org/10.1016/S0167-1987(99)00086-0.

Trapeznikov, V.K., Ivanov, I.I., Kudoyarova, G.R., 2003. Effect of heterogeneous distribution of nutrients on root growth, ABA content and drought resistance of wheat plants. Plant Soil 252, 207-214.

United States Department of Agriculture (USDA), 2012. Soil Taxonomy. USDA-NRCS, Washington, DC, USA.

Vepraskas, M.J., 1994. Plant response mechanisms to soil compaction. In: Wilkinson, R. (Ed.), Plant Environment Interactions. M. Dekker, New York, pp. 263-287.

Weligama, C., Tang, C., Sale, P.W.G., Conyers, M.K., Liu, D.L., 2008. Localized nitrate application together with phosphorus enhances root proliferation of wheat and maximizes rhizosphere alkalization in acid subsoil. Plant Soil 312, 101-115. https:// doi.org/10.1007/s11104-008-9581-9. 